\title{
THE PLACE OF WORSHIP IN SOLEMNIZATION OF A MARRIAGE
}

Under the 1949 Act a marriage can be solemnised in an Anglican church by a clergyman; in a registered building (being a certified place of worship) in the presence of an authorised person or registrar; in approved premises in the presence of a registrar. The essential elements are the place of the ceremony and the presence of one of the designated officials. MA v JA ....

In introducing a facility to enter into a civil marriage on approved premises, hedged around by Regulations governing approval and by a requirement ... for the presence at the wedding of both the superintendent registrar and the local registrar..., Parliament in 1994 clearly proceeded on the basis that a building would secure registration for the solemnisation of marriages under section 41 only if it truly was a place of public religious worship.

Regina (Hodkin and another) v. Registrar General of Births, Deaths and Marriages ${ }^{2}$

In two recent English cases, the significance of "place" in the valid solemnization of a marriage has been highlighted. In the first case, $M A v J A$ (2012), a question arose as to the validity of a marriage celebrated in Muslim form in a mosque. There was no doubt as to the parties' intention to get married, but they were uninformed as to the law of marriage and failed to obtain a license. Furthermore, the imam officiating at the wedding did not realize that the parties wanted the marriage to be a legally binding one, rather than merely a religious

\footnotetext{
${ }^{1}$ [2012] EWHC 2219 (Fam), [2012] All ER (D) 338.

2 [2013] UKSC 77; [2013] WLR (D) 492.
} 
celebration following a civil wedding. In line with previous cases where an irregular marriage has taken place and the court has to decide whether it is valid or non-existent, ${ }^{3}$ Moylan $\mathrm{J}$ had to consider whether the steps undertaken included sufficient "hallmarks of marriage" to be a marriage for the purposes of the Marriage Act 1949. In that context, he deemed neither the exchange of vows nor the obtaining of a license to be decisive. Indeed in an earlier case a license was described as merely "part of the preliminary paperwork provided by the state to the parties and the officiating minister to indicate a fulfilment of, or compliance with the requirements of capacity to marry and the like... [I]t is no more than that". ${ }^{4}$ On the other hand, Moylan J considered it essential that the marriage should take place in a registered place of worship.

In the second case, $R$ (Hodkin and another) v. Registrar General of Births, Deaths and Marriages (2013), the United Kingdom Supreme Court addressed difficult questions concerning the nature of religion and of religious worship for the purpose of deciding whether a Church of Scientology could be registered as a place of worship for the purpose of solemnization of a marriage. It is logical to assume that a decision on such weighty matters by the highest court in the land was elicited for grave reasons.

These cases, whether through their wording or the significance of the issues decided merely as a preliminary to registering premises for a marriage, indicate that the place of solemnization of marriage is central to the validity of the marriage itself, a conclusion that

\footnotetext{
${ }^{3}$ The nullity of a marriage for failure to comply with certain provisions of the Marriage Act 1949 is stated in s.49 of that Act, but in each case the non-compliance must be "knowing and wilful".

${ }^{4}$ Burns v Burns [2008] 1 FLR 813.
} 
may seem surprising. This article contributes to an understanding of "place" in the law regulating the formalities of marriage, and current challenges to its central role.

Section A explains how place, and more specifically "place of worship", emerged as a constituent element in the celebration of a valid marriage. It traces how the Catholic Church, competing with family and kinship groups, gradually exerted control over the substance and formalities of marriage, so that eventually most marriages were celebrated in a church. Just at the point in time when this control had become virtually complete, however, the rise of the nation State, combined with changes in the sources and allocation of wealth and with Reformation ideas and conflicts, led to the emergence of new interests to be satisfied. The different trajectories of the struggles between rival political and religious factions have had a lasting influence on the law concerning the formalities of marriage

Section B then highlights some of the problems of complexity in the modern English law governing marriage at a registered place of worship, and the particular impact of the Marriage (Same Sex Couples) Act 2013. The choice to use place of worship as a significant element in the formalities of marriage has led to an accumulation of technical amendments to the law. Moreover, a comparative survey of laws on the solemnization of marriages (Section C) demonstrates the exceptional character of the approach adopted by English law. But, it also highlights some of the problems arising out of alternative solutions. A particular issue being confronted in a number of jurisdictions is a rising demand for marriages which are secular but nevertheless personally meaningful to the parties involved - a demand which is not adequately met by marriages at vital statistics offices or in other bureaucratic environments.

Finally the article will examine the attempts that have been made in recent decades to reform English law in respect of the formalities of marriage and the factors that have prevented such reform (Section D), before surveying the recent drivers for change that seem 
destined to dethrone 'place' as an essential element in a valid marriage and the interests that any reform of the law should strive to satisfy (Section E).

\section{A - THE SIGNIFICANCE OF PLACE OF WORSHIP IN THE SOLEMNIZATION OF} MARRIAGES: A BRIEF HISTORY

(i) Marriage in facie ecclesiae: place introduced

In the pre-Christian era in Europe, marriage was a private affair. Roman and Germanic marriages were negotiated between families. A marriage was a contract, and parental control was of the essence. ${ }^{5}$ In this context the place of the marriage was irrelevant (except in so far as it reflected the power relationship between the families concerned).

The early Church, reflecting the culture within which it was embedded, was content to work within this framework of marriage laws. ${ }^{6}$ It was not until after the fall of the Roman Empire that the Church began to impose its own view of marriage, not until the $11^{\text {th }}$ century

\footnotetext{
${ }^{5}$ R.H.Helmholz, Marriage Litigation in Medieval England (Cambridge: Cambridge
} University Press, 1974), 4-5; G.E. Howard, A History of Matrimonial Institutions Chiefly in England and the United States with an Introductory Analysis Vol.1 (Chicago: University of Chicago Press, 1904), 156 ff; Mary Ann Glendon, The Transformation of Family Law: State Law and Family in the United States and Western Europe (Chicago: University of Chicago Press, 1989), 19 ff.

${ }^{6}$ In the mid-eleventh century, the Decretum of Gratian - the basic text on which the masters of canon law lectured and commented in the universities - stated that "clandestine marriage should not be made" (Case 30, Q.5, C.1). See also Case 32, Q 2, C.12 and Case 30, Q.5, C.3. 
that the canon law of Rome began to develop, and only in the $12^{\text {th }}$ century that marriage was first recognized as a sacrament. ${ }^{7}$ Over the centuries, a tradition of celebrating a marriage at the church door developed. ${ }^{8}$ The formal celebration of the marriage was according to custom, but was followed by a bride-mass. Then from the $13^{\text {th }}$ century onwards, priestly involvement in the solemnization of the marriage itself became more common, and the ceremony gradually moved to the interior of the church. ${ }^{9}$

This was nevertheless by no means a smooth process. During the $12^{\text {th }}$ century it became established as a principle of canon law that "consent in the present tense" without consummation was sufficient to create a valid marriage. ${ }^{10}$ However theologically sound that

\footnotetext{
${ }^{7}$ Helmholz, Marriage Litigation, 45; Howard, Matrimonial Institutions, 332.

${ }^{8}$ Howard, Matrimonial Institutions, 295 ff.
}

${ }^{9}$ Ibid. 309. This move is linked to changes in marriage customs which began to allow the bride to appoint a marriage officiant: "[F]rom the moment that custom sanctioned the choice of any third person in place of the father or other natural protector, the clergy appropriated this function as their exclusive right. While the church 'bestowed her blessing upon tradition through the natural guardian, she directed against the lay chosen guardian her excommunication.'" (quoting Sohm, Das Recht der Eheschliessung (Weimar, 1875) 164).

${ }^{10}$ James A. Brundage, Law, Sex and Christian Society in Medieval Europe (Chicago: University of Chicago Press, 2009), 268-269. This had been a much contested question, and in the medieval period generated a large case law analyzing whether particular forms of verbal expression constituted consent in the present tense (per verba de praesenti): Howard, Matrimonial Institutions, 340 ff. Helmholz, Marriage Litigation, 25-73. 
proposition might be, it weakened parental control over marriages, ${ }^{11}$ and at the same time undermined the efforts of the Church to assert control. Lay marriage was declared by the Church to be illegal, but it was nevertheless valid. Ecclesiastical sanctions, which were the only penalty for breach of canon law rules concerning the involvement of the Church in marriages, including an obligation to publicize the ceremony through the calling of banns, had insufficient dissuasive effect. It was possible for couples to marry

"in a house, in the street, in the fields, or at a tavern ... It was possible for a young man balancing on a ladder to slip a ring onto the finger of a thirteen-year-old girl through the grating of her window, or for two lovers to exchange consent while touching hands through a hole in the wall."12

${ }^{11}$ At a time when developing rules of primogeniture made parental control over marriage increasingly important: Charles Donoghue Jr., "Law, Marriage, and Society in the Later Middle Ages: A Look at the English and 'Franco-Belgian' Regions”, in Proceedings of the Thirteenth International Congress of Medieval Canon Law (Esztergom-Budapest, August 39, 2008), Monumenta Iuris Canonici C:14, ed. Peter Erdö and Sz. Anzelm Szuromi, (Città del Vaticano: Biblioteca Apostolica Vaticana, 2010), 17-39.

${ }^{12}$ Cecilia Cristellon, "Does the Priest Have to Be There? Contested Marriages before Roman Tribunals: Italy, Sixteenth to Eighteenth Centuries," Österreichische Zeitschrift für Geschichtswissenschaften 20:3 (2009): 17. 
In England, ${ }^{13}$ litigation concerning the validity of marriages was a prominent feature of court business during the thirteenth and fourteenth centuries. Helmholz notes:

We must see the process by which the church vindicated its control over marriage as a longer and more gradual process than has hitherto been thought. It did not come with the definitive formulation of the classical canon law in the twelfth century. Rather it was the product of slow growth and acceptance. ${ }^{14}$

It was not until the sixteenth century, at the Council of Trent, that the step was taken to make validity of marriages dependent on certain requirements of form. The Tametsi decree of 1563 finally required the presence of the parish priest for a valid marriage. But even then, the place of marriage was not determinative. The marriage did not have to take place in the church itself. ${ }^{15}$

${ }^{13}$ Howard, Matrimonial Institutions, 310 f., comparing English and French sources, suggests that priestly control of marriage was relatively slow to develop in England. He also notes that marriage at the church door continued to be common in England until the $16^{\text {th }}$ century. The liturgies of Edward VI and Elizabeth I were the first to require the ceremony to be performed in the body of the church.

${ }^{14}$ Helmholz, Marriage Litigation, 72. Canon law rules on marriage were significantly in conflict with previous traditions. For example, earlier customs did not regard marriage as indissoluble. Moreover, marriages within kinship groups were likely to be found invalid as within the prohibited degrees.

${ }^{15}$ See now Can.1118 of the 1983 Code of Canon Law, under which marriage in a church is the default position, but marriage in another "suitable place" may be authorized. 
(ii) Laying the groundwork: a rejected experiment and a monitoring system

At about the time that the Tametsi decree was reflecting the control the Catholic Church had obtained over marriage, wholly new challenges were being faced as a result of economic, political and religious upheavals in Europe. The decline of the feudal system and the rise of new centers of wealth and education, the rise of the nation state, religious pluralism as a result of the Reformation - all these undermined the claims of the Catholic Church to universal authority, and in the process the impact of the Tametsi decree.

New ideas about the nature of marriage emerged. Reformation theologians denied that marriage was a sacrament, or that it fell within ecclesiastical competence. The various Protestant traditions each "provided a different theological formula for integrating the inherited contractual, natural, and spiritual perspectives on marriage", ${ }^{16}$ but, initially at least, they drew on existing canon law as to the actual formalities for marriage. ${ }^{17}$ Nevertheless, in some States, the conception of marriage as a civil rather than an ecclesiastical matter led to more radical innovations. In parts of the Netherlands a civil alternative to religious marriages was introduced in the late $16^{\text {th }}$ century as a result of the Reformation. From the 1570 s the cities of Amsterdam, Rotterdam and Gouda allowed marriage before a civil authority, ${ }^{18}$ and

${ }^{16}$ John Witte Jr., "Church, State, and Marriage: Three Reformation Models," Word \& World 23 (2003): 42.

${ }^{17}$ Ibid. 44.

${ }^{18}$ Variously a magistrate, notary or the aldermen of the city: Henk Looijesteijn and Marco H.D. van Leeuwen, "Establishing and Registering Identity in the Dutch Republic," in Registration and Recognition: Documenting the Person in World History (Proceedings of the 
in 1580 the province of Holland introduced a uniform marriage law which provided the option of marrying before a minister of the Dutch Reformed Church or a magistrate. ${ }^{19}$

Civil marriage was also introduced in England. In the period between the break from Rome and the Civil War, despite much dissatisfaction and calls for changes in the law, new measures relating to the regulation of marriage were few and limited. ${ }^{20}$ But one of the legislative measures enacted during the Commonwealth period was the 1653 Act touching Marriages and the Registring thereof; and also touching Births and Burials. The Act was extraordinarily radical, in that it prohibited marriages performed by the clergy ${ }^{21}$ and introduced civil marriage, performed by the Justice of the Peace, as the only valid form.

British Academy 182), ed. Keith Breckenridge and Simon Szreter (Oxford: Oxford University Press, 2012), 214-219. Regulation of marriage was regarded as a priority in order to prevent property disputes. All those intending to marry had to appear before civil authorities and provide evidence of $e$.g. name, address, parental consent before being given permission to publicize the wedding.

${ }^{19}$ Ibid. Again the legislation also included measures concerning publicity and parental consent to prevent clandestine marriages.

${ }^{20}$ Canons were enacted in 1571, 1575, 1584, 1597, 1604 and 1640: Richard H. Helmholz, The Oxford History of the Laws of England: Volume I - The Canon Law and Ecclesiastical Jurisdiction from 597 to the 1640s (Oxford: Oxford University Press 2004), 264-9. The core rules regulating marriage remained unchanged, however. Modifications included raising the age of valid consent to marriage to sixteen for boys and fourteen for girls, and clarifying the circumstances in which a license to marry without banns could be issued.

${ }^{21}$ This prohibition was withdrawn in 1657 . Thereafter both civil and religious ceremonies were permitted until 1660. 
McLaren comments on the good order and reliability of the registers of marriage during the Commonwealth period. ${ }^{22}$ Nevertheless, along with other interregnum measures, the 1653 Act was immediately repealed in 1660 with the restoration of the monarchy. The "Act for Confirmation of Marriages" confirmed that marriages made under Cromwell's legislation were to be regarded as if they had been solemnized according to the rites and ceremonies of the Church of England. ${ }^{23}$ The Puritan experiment was over, and a reversion to tradition was celebrated.

A feature of the law of 1653 was the fact that members of all religious groups were treated equally. A civil marriage was essential in each case. Reversion to the ecclesiastical regulation of marriages reintroduced religious discrimination. When Anglicanism was revived as the state religion only an Anglican marriage was recognised as valid. This was consistent with other restrictions on non-Anglicans imposed by a state fearful of renewed religious hostilities and endorsed by a people who had chafed under enforced Puritanism. Under the Test and Corporation Acts, introduced as from 1661, the taking of communion in an Anglican Church was a precondition for any civil or military office, and for access to university. The Act of Uniformity of 1662 prescribed the acceptable form of prayers, administration of sacraments and other rites for the established church. It led to the ejection of from Anglican churches of all "non-conformists", who fractured into smaller dissenting

${ }^{22}$ Dorothy McLaren, "The Marriage Act of 1653: Its Influence on the Parish Registers" Population Studies 28 (1974): 319 - challenging the view that many people ignored the new marriage laws and continued as before. Just as today, the existence of a civil wedding need not have ruled out a parallel religious one.

${ }^{23}$ R.B. Outhwaite, Clandestine Marriage in England: 1500-1800 (London: Hambledon Press, 1995), 13. 
groups. ${ }^{24}$ Within a few years the violent reaction against Puritanism had subsided and a greater degree of toleration was advocated. New ideas of political philosophy and economy promoted toleration as conducive to commercial growth: acceptance of differences in the spiritual realm allowed collaboration in temporal matters such as trade and industry. Among other things, the Act of Toleration 1689 allowed dissenters to establish their own places of worship. But controls were still in place: no assembly for religious worship was allowed until the place of meeting had been certified, ${ }^{25}$ nor was preaching permitted except with open doors. It is this legislation on registration of places of worship that established the foundation on which later regulation of non-Anglican marriages has been built.

\section{(iii) Lawless churches: place subverted}

An expectation that marriage should normally take place in a church does seem to have become established by the $18^{\text {th }}$ century, ${ }^{26}$ but the fees charged for marriage licenses - which granted permission to marry despite the existence of some substantive impediment or to dispense with a procedural requirement (such as the publishing of banns in a particular

${ }^{24}$ Further restrictions were also imposed by the Quaker Act 1662, the Conventicle Act 1664 and the Five Mile Act 1665.

${ }^{25}$ Section XIX.

${ }^{26}$ In Marriage Law and Practice in the Long Eighteenth Century (Cambridge: Cambridge University Press, 2009), Rebecca Probert demonstrates that by this time private exchanges of vows (per verba de praesenti) were interpreted as contracts to marry, which could be enforced by the ecclesiastical courts. It was expected that the marriage itself would take place in a church. 
location) - became a lucrative source of income for the clergy, ${ }^{27}$ many of whom became increasingly cavalier about compliance with the canon law rules they were supposed to enforce. So called "lawless churches" sprang up, offering their services to those who sought a quick or private wedding. ${ }^{28}$

Most notable in the early eighteenth century was the growth of Fleet marriages. Since the Fleet was a debtors' prison, clergymen offering their services from the Fleet essentially had nothing to lose from the imposition of further fines. Penalties on the Warden of the Fleet eventually stopped weddings taking place in the prison chapel itself, but business spilled out into the surrounding streets: to the taverns and ale houses. A Fleet wedding offered convenience, reduced expense and entertainment laid on. ${ }^{29}$ It might be irregular, but it was legally valid. It has been estimated that by the 1740s as many as seventy per cent of marriages in London may have taken place in the Fleet. ${ }^{30}$ Few questions were asked about the

${ }^{27}$ Jeremy Boulton, "Itching After Private Marryings? Marriage Customs in Seventeenth-century London,” The London Journal 16 (1991): 15; John R. Gillis, For Better, for Worse: British Marriages, 1600 to the Present (Oxford: Oxford University Press, 1985), 90: "While the bishops retained nominal control over sale, they often issued blanks to surrogates among the parish clergy, who, for the sake of the lucrative fees, made mockery of the controls on age and parental consent they were supposed to administer. Both bishops and surrogates were supposed to administer oaths and demand securities, but these too were laxly attended to."

${ }^{28}$ Outhwaite, Clandestine Marriage, 15-26; Gill Newton, "Clandestine marriage in early modern London: when, where and why?" Continuity and Change 29:2 (2014): 151

${ }^{29}$ Gill Newton, "Clandestine marriage in early modern London".

${ }^{30}$ Boulton, "Itching After Private Marryings?". 
identity and age of the parties, and there was a willingness to falsify the records for financial inducement. These were "religious" marriages in name only.

Parliamentary efforts to bring order to the law on solemnization of marriage were for a long time frustrated by the strongly conflicting interests of Lords and Commons. Property owners sought parental control over marriage - or at least adequate notice of a proposed marriage - so that they could ensure any alliance entered into was advantageous. There was always the risk of a fortune hunter whisking away an heir or heiress. On the other hand, the less wealthy were inclined to see marriage as an opportunity for advancement and resisted such restrictions. Moreover, the legislative proposals brought before the Commons tended to impose harsher penalties for infringement on the serving classes than their masters and so proved objectionable on several grounds. ${ }^{31}$

(iv) The Marriage Acts 1753 to 1949: place enthroned

Legislation regulating marriage was finally passed in 1753 under the close supervision of the Chancellor, Lord Hardwicke (the 1753 Act, or Lord Hardwicke's Act). Lord Hardwicke had presided in several cases involving clandestine marriages and so had a particular interest in the subject. Stone suggests that the success of the 1753 Act, after decades of failed initiatives, sprang from, inter alia, Lord Hardwicke's close attention to drafting and finding common ground between factions, as well as "the use of rhetoric, logic, cajolery, and behindthe-scenes threats, deals and lobbying", 32

${ }^{31}$ Outhwaite, Clandestine Marriage, $65 \mathrm{ff}$.

${ }^{32}$ L. Stone, Road to Divorce: England 1530-1987 (Oxford: Oxford University Press, 1990)

122-123. See also for the passage of the Act, Outhwaite, Clandestine Marriage, Ch 4. 
While Lord Hardwicke's Act contained a number of radical features, its most striking innovation was the fact that it rendered invalid marriages not conducted in accordance with the prescribed formalities - thus employing the approach that had been adopted by the Catholic Church in the Tametsi decree two hundred years previously. ${ }^{33}$ The prescribed formalities under Lord Hardwicke's Act were nevertheless more stringent. A marriage, in order to be valid, had to take place in a parish church or public chapel, be preceded by banns or a license, and be conducted by a minister of the Church of England. ${ }^{34}$ The rules on banns and licenses meant, in effect, that the marriage had to take place in the church of the parish where the one of the parties had been living for the previous four weeks. For the first time, location mattered - not just as a matter of convenience for administrative purposes, or a rule of ecclesiastical law often honored in the breach, but as a binding legislative requirement for a valid marriage. Moreover, the rules relating to location encompassed both place of residence and place of worship. These provisions were designed to eliminate clandestine marriages, and more particularly to limit marriages without parental consent. ${ }^{35}$ Penalties for

\footnotetext{
${ }^{33}$ One factor in the success of the legislation was the changing attitude of society towards ecclesiastical laws and the binding nature of an exchange of promises: see Outhwaite,
} Clandestine Marriage, 87.

${ }^{34}$ An exception was retained for the Archbishop of Canterbury’s Special Licence, under which the marriage could be celebrated at any time and in any place. This enabled the wealthy to continue to conduct private ceremonies at home.

${ }^{35}$ They were further supported by a legal rule to the effect that the marriage of a minor by license was invalid without parental consent. In the case of marriage of a minor by banns, the banns were invalid where parental objections were made known. 
members of the clergy who infringed the law were strengthened. Rather than a fine or suspension, they risked transportation for fourteen years.

Any continuing confusion over the status of a mere exchange of promises was thereby at an end, ${ }^{36}$ and for the "poorer sort" protection against seduction and bigamy was secured by the rules on location and publicity. The penalties on clergymen produced their effect, and the marriage trade in the centers for clandestine marriages quickly collapsed. ${ }^{37}$

Although there was a variety of calls for the reform or repeal of the 1753 Act, it remained in force for the next seventy years. Amendment, followed by repeal and replacement, occurred in 1823 , and further reforms followed in $1836 .{ }^{38}$ One concern was the fact that the strictness of the criteria for validity in the 1753 Act could operate harshly in some circumstances, and could be open to abuse. ${ }^{39}$ But a further cause of dissatisfaction was the position of non-conformists and Roman Catholics under the Act. At the time it was adopted, both were in a weak position. Quakers and Jews lobbied for exceptional treatment, which they could justify on the basis of the fact that they had a long tradition of marriage according to their own rites, and that they kept diligent records of those marriages. The Act specifically stated that "nothing in this Act contained shall extend to" marriages between Jews and between Quakers, but non-conformists and Roman Catholics were obliged to marry

\footnotetext{
${ }^{36}$ See Outhwaite, Clandestine Marriage, 84.

${ }^{37}$ Outhwaite, Clandestine Marriage, 127.

${ }^{38}$ For details see Outhwaite, Clandestine Marriage, Ch 7 and Stephen Cretney, Family Law in the Twentieth Century: A History (Oxford: Oxford University Press, 2003), Ch1. ${ }^{39}$ The 1823 Marriage Act provided that a marriage would only be automatically void if the parties had "knowingly and wilfully" failed to comply with its formal requirements. Where one of the parties was an innocent dupe, therefore, the marriage could no longer be annulled.
} 
in an Anglican church unless they could afford a special license from the Archbishop of Canterbury. By the early $19^{\text {th }}$ century, however, the Evangelical Revival had produced more confident and assertive Protestant denominations, and it had become widely accepted that expecting non-conformists to participate in an Anglican marriage ceremony contrary to their beliefs was both disrespectful to them and demeaning to the Church. Initial Dissenters' Marriages Bills passed in the House of Commons foundered in the House of Lords, but in the 1830s the project for "dissenting marriages" became linked to the establishment of a central population register, and this provided the way to an acceptable solution for both nonconformists and Catholics. ${ }^{40}$ The General Register Office and the office of Superintendent Registrar were created in 1836 by the Act for registering Births, Deaths, and Marriages in England. Marriage under a registrar's certificate - providing the publicity and verification functions provided by banns in the case of Anglican marriages - was also introduced by the Act for Marriages in England which was adopted on the same date (the 1836 Act). Under the latter Act, a place certified as a place of worship could be registered for the celebration of marriages therein. The form and ceremony of the marriage were a matter for the church concerned, provided that a specified form of words was used to express consent to marriage and the marriage was solemnized in the presence of a registrar and two witnesses. ${ }^{41}$

\footnotetext{
${ }^{40}$ Rebecca Probert, Marriage Law and Practice, ch.9.

${ }^{41}$ The requirement that a registrar be present continued to be a source of grievance until it was removed by the Marriage Act 1898. See further, Cretney, Family Law in the Twentieth
} Century, 19-20. 
Since the preceding legislation ${ }^{42}$ used the place of marriage as an important factor in its regulatory framework, it was perhaps logical to conceive of the regulation of the marriages of other religious denominations in a similar way and to focus on the (registered) place of worship. The option of marriage in a register office was included in the 1836 Act for "persons who shall object to marry under the Provision of this Act in any such registered building". It was clearly the expectation that religious marriages would be the norm, and the register office option was for people with strong conscientious objections. ${ }^{43}$ In recent years, however, the proportion of marriages taking place in a register office has reached 70 per cent. $^{44}$

${ }^{42}$ The most recent prior legislation, the 1823 Act for Amending the Laws respecting the Solemnization of Marriages in England, required publication of the banns in the church or chapel for the parish where the parties were resident, and solemnization of the marriage in that church or chapel "and in no other place whatsoever".

${ }^{43}$ Hansard includes a speech by the Bishop of London in 1839 - complaining of the harm done to the Church by the new law on registration of births because there was no longer any necessary connection with baptism - to the effect that " $[\mathrm{t}]$ he Marriage Act would do but little harm, because it would never be much acted on..." HL Deb March 5, 1839 series 3, vol. 45 cc1253-61

${ }^{44}$ Statistics from 1837-2010 relating to the form of ceremony can be found in ONS Release Marriages in England and Wales (Provisional), 2011 (June 26, 2013), in Table 2 of the reference table providing details marriages by area of occurrence, type of ceremony and denomination, accessed October 2, 2013, http://www.ons.gov.uk/ons/publications/rereference-tables.html?edition=tcm\%3A77-292280. 


\section{(v) Conclusions}

There is a long history of conflicting interests as to the rules on the formalities of marriage. The Church sought slowly to instill its vision of marriage into the peoples it served, and once it had recognized marriage as a sacrament, it had an incentive to exert control over the conduct of marriages. It could also offer the advantages of infrastructure and an educated priesthood - promoting certainty and allowing record keeping. But the rule of canon law that "consent in the present tense" was sufficient for the formation of a valid marriage prevented the Church from capitalizing on these advantages. In particular, it placed the Church in conflict with the landowning classes, who wanted marriage to be subject to greater formalities so that they were better able to control the marriages of their offspring. And that desire increased as a result of the incentives provided by the laws of property and inheritance. At the same time, there seem always to have been those entering into marriage who, for good reasons or bad, have desired to preserve the privacy and individuality of their actions.

These conflicts remained unresolved until the particular constellation of events which permitted the adoption of Lord Hardwicke's Act - including a tradition of church marriage which had by the $18^{\text {th }}$ century become settled, concern over several high profile clandestine marriages, disapprobation of Fleet marriages, and the brokering skills of Lord Hardwicke himself. It is only through the 1753 Act that the place of marriage becomes an element essential to validity. Since 1753, in England and Wales, regulation of the places in which a marriage may validly be solemnized has become an integral element of the legislation governing marriage. As a consequence, the legislation requiring non-conformist places of 
worship to be registered has continued in being almost solely for the purpose regulating marriages. ${ }^{45}$ The next section will explore the current complex rules on place of marriage.

B - REGISTERED PLACE OF WORSHIP WITHIN THE FRAMEWORK OF THE 1949 MARRIAGE ACT

(i) General principles

The Marriage Act 1949 (the 1949 Act), represents a consolidation of the previous legislation, including various "minor amendments". ${ }^{46}$ In view of the controversy that has habitually attached to legislation on marriage, it is noteworthy that the 1949 Act was passed by Parliament under the Consolidation of Enactments (Procedure) Act 1949, allowing it to be adopted without full debate by both Houses.

The focus on "place" remains evident in 1949 Act. The Act is divided into six parts, of which Parts II and III are the principal ones relevant to this topic. ${ }^{47}$

${ }^{45} \mathrm{~A}$ further reason for registering is to obtain exemption from business rates. It is, however, clear from the Explanatory Note to s.68 of the Local Government Act 2003 that registration is merely a convenient evidence of entitlement to exemption. In 2003 it was anticipated that the Places of Worship Registration Act 1855 would be repealed as a result of proposed changes to the law governing marriage (see further on these proposed changes below at $49 \mathrm{ff}$.) ${ }^{46}$ See further Cretney, Family Law in the Twentieth Century, 23-24.

${ }^{47}$ Part I of the 1949 Act deals with restrictions on marriage, such as the prohibition of marriages between those who are closely related and the age at which the parties can lawfully marry (with or without the consent of a parent or guardian); Part IV deals with the particulars 
Part II of the Act deals with the current rules on marriage according to the rites of the Church of England. Marriage following the publication of banns continues to be available. It is possible to dispense with banns under a (common or special) license or Superintendent Registrar's certificate. ${ }^{48}$ The fundamental objective of these rules is to ensure that adequate publicity is given to the marriage in the parish or parishes where the parties live, so that objections to the marriage can be raised if appropriate, and that additional checks on compliance with the criteria for capacity to marriage are made before the issue of a license or certificate which grants dispensation from the requirement to call banns. ${ }^{49}$ The locations in which banns may be published is therefore regulated in the Act. Under s.12 a marriage may only be solemnized in a church or chapel where the banns have been published, and under s.6 the banns must be published in the parish where at least one of the persons to be married is resident, or in the parish which is the "usual place of worship of the persons to be married or

of registration of marriages and maintenance of records; Part V ensures that the scheme of the act applies to naval, military and air force chapels; and Part VI sets out certain general provisions, including statutory offences relating to the solemnization and registration of marriages.

${ }^{48}$ The greater freedom of time and place of marriage under the Archbishop of Canterbury's special license also continues to exist. It was supplemented in 1970 by similar provision for non-Anglican marriages under a Registrar General's Certificate (Marriage (Registrar General's License) Act 1970), but restricted to cases where one of the intending parties to the marriage is seriously ill and not expected to recover, and so cannot be moved.

49 As a result of doubts about the effectiveness of these checks, an Immigration Bill currently before Parliament is introducing compulsory civil preliminaries in cases where one of the parties is a non-EEA national: Immigration, HC Bill (2013-14) [128]. 
of one of them". ${ }^{50}$ The ceremony itself is not regulated by the statute, being left to Anglican canon law.

Alternative ways of getting married must be authorized by Superintendent Registrar's certificates and are regulated by Part III of the Act, which has undergone several amendments since 1949. The variety of marriages that may now be authorized under a certificate, some of which are defined by location and some by the rites or usages employed, are now set out in s.26(1)(a)-(e) of the 1949 Act:

(a) a marriage in a registered building according to such form and ceremony as the persons to be married see fit to adopt;

(b) a marriage in the office of a Superintendent Registrar;

(bb) a marriage on approved premises;

(c) a marriage according to the usages of the Society of Friends (commonly called Quakers) $;^{51}$

(d) a marriage between two persons professing the Jewish religion according to the usages of the Jews;

(dd) the marriage (other than a marriage in pursuance of paragraph (c) or (d) above) of a person who is house-bound or is a detained person at the place where he or she usually resides;

(e) a marriage according to the rites of the Church of England in any church or chapel in which banns of matrimony may be published.

${ }^{50}$ But see further below at 23-24.

${ }^{51}$ This provision may be contrasted with the following one, under which both persons must profess the Jewish religion. Section 47 establishes when a marriage according to the usages of the Quakers may be authorized even if one of the parties is not a Quaker. 
The exceptional position of Jews and Quakers, first introduced in Lord Hardwicke's Act, has been retained in the 1949 Act. Although the original legislation did not confer validity on Jewish and Quaker marriages ${ }^{52}$ - it merely stated that "nothing in this Act contained shall extend to" marriages among these groups - the 1836 Act "confirmed" that the marriages of Jews and Quakers according to their "usages" were good in law and legislation since that date has maintained their separate status, and has used wording that clarifies the point that such marriages are valid. The place of solemnization is not, therefore, legally relevant to the validity of such marriages.

The 1949 Act also retains the approach introduced by the 1836 Marriage Act in relation to solemnization of marriages by other religious bodies. Marriage in a registered building is permitted "according to such form and ceremony as the persons to be married see fit to adopt" ${ }^{53}$ A registered building for this purpose must be a registered place of worship under the Places of Worship Registration Act 1855 and also be registered for the solemnization of marriages under s.41 of the 1949 Act. The requirement in s.41 of the 1949 Act as originally drafted that a "separate" building certified as a place of worship may be registered for the solemnization of marriages proved to be an obstacle to the registration of mosques in the 1980s, since mosques unite various functions and no separate place of worship can be identified. Amending legislation was therefore introduced in 1990 to remove the requirement of separateness. ${ }^{54}$

52 Rebecca Probert, Marriage Law and Practice, 234.

${ }^{53}$ Subject to the consent of the minister or one of the trustees, owners, deacons or managers of the building (s.44 of the 1949 Act).

${ }^{54}$ The Marriage (Registration of Buildings) Act 1990. 
The emphasis on a designated place for marriages has proved to be something of a straitjacket. Not every church or registry office is an attractive location for a wedding. Towards the end of the twentieth century, as cohabitation became less stigmatized and average incomes rose, couples saved for a glamorous event to celebrate their relationship. In response to demand, the Marriage Act 1994 amended the 1949 Act, adding s.26(1)(bb), which allows civil marriages to take place at "approved premises", ${ }^{55}$ as authorized by local authorities, Such premises must be a "seemly and dignified venue for the proceedings". ${ }^{56}$ Hotels and stately homes feature in lists of approved premises, along with museums and even underground caverns, but ceremonies in the open air or in a marquee are not permitted.

The pressure to extend the locations available for marriage ceremonies has also been felt by the Church of England, particularly as a result of the availability of new and attractive “approved premises”. The Church of England Marriage Measure 2008 has relaxed the rules on the places in which a marriage can be solemnized. ${ }^{57}$ In substance, the Measure allows a

${ }^{55}$ Approval of premises is dealt with in s.46A of the 1949 Act. It provides for regulations to be made governing approval by local authorities of premises for the solemnization of marriages. The current regulations are the Marriages and Civil Partnerships (Approved Premises) Regulations 2005 (as amended).

${ }^{56}$ Marriages and Civil Partnerships (Approved Premises) Regulations 2005, Sch.1 Para.1. See also The Registrar General's Guidance for the Approval of Premises as Venues for Civil Marriages and Civil Partnerships (6 ${ }^{\text {th }}$ ed, General Register Office, 2013).

${ }^{57}$ See ss.6, 12, 15 and 16 of the Act. For an explanation of Church of England Measures, see Russell Sandberg, Law and Religion (Cambridge: Cambridge University Press, 2011), 62-63. 
person to marry in a given parish if he or she can establish one of five "qualifying connections" with that parish. These include, by way of example, baptism or confirmation in the parish, regular public worship there for a period of six months at any time, and the marriage of a parent or grandparent there.

No mixing of civil and religious ceremonies is permitted. ${ }^{58}$ Thus a civil ceremony should not include any religious elements. The 1949 Act specifically provides in s.46 for the option of having a religious ceremony after the civil one, making it clear that it is the civil ceremony that creates the valid marriage.

Part III of the 1949 Act further specifies that the marriage should take place in the presence of a registrar (or, in the case of marriage solemnized in a registered building, an authorized person ${ }^{59}$ ) and with two additional witnesses. The premises should, so far as possible, be open to the public - in continued recognition of the role of publicity in regulating marriage. ${ }^{60}$

(iii) The Marriage (Same Sex Couples) Act 2013

The law relating to marriage, including the law relating to the registration of places of worship for the solemnization of marriage, has now been given a new layer of complexity by

The 2008 Measure co-exists with the 1949 Act without directly amending it, and requires the provisions of the Act on the publication of banns and the issue of certificates confirming the publication of banns to be read "as if" they incorporate the provisions of the Measure.

${ }^{58}$ Sections 45(2), 45A(4) and 46B(4).

${ }^{59}$ Section 43 deals with the appointment of authorized persons, who are responsible for registration of the marriage.

${ }^{60}$ See ss.44(2), 45(1) and 46B(2). 
the Marriage (Same Sex Couples) Act 2013. This legislation, while in principle about the meaning of marriage and equal access to that institution, includes a further series of amendments to the 1949 Act in order, in particular, to deal with issues of conscience and the position of faith groups in relation to the solemnization of marriage. ${ }^{61}$ A marriage of a samesex couple may not be performed under Part II of the 1949 Act according to the rites of the Church of England without new legislation being brought forward. ${ }^{62}$ Other religious organizations will not automatically be able to conduct same-sex marriages under the Act but will have to "opt-in". ${ }^{63}$

${ }^{61}$ The possibility of a conscience clause for registrars was raised several times by way of amendment to the Marriage (Same-Sex Couples) Bill, but was rejected: see Marriage (SameSex Couples) Bill Deb 26 February 2013, col 220 ff and Deb 12 March 2013, col 268 ff; HC Deb 20 May 2013, col 926 ff (and especially col 934); HL Deb 17 June 2013, col 103 ff and HL Deb 8 July 2013, col 39 ff.

62 The Church of England itself may legislate for this by Measure, which will then require Parliamentary approval by an affirmative Resolution of each House. If the Church in Wales decides it wants to solemnise same-sex marriages, then the Lord Chancellor "must" bring forward the necessary amending legislation: s. 8 of the 2013 Act.

${ }^{63}$ As well as the possibility of "opting in" to the celebration of same sex marriages, the Act also provides for the possibility of "opting out" - that is, reversing the opt-in procedure in relation to any of its constituent elements. The opt-in and opt-out elements are listed in a table in s.2(3) of the 2013 Act . They include giving consents, applying for the registration of a building, and authorizing a person to be present at the solemnization of a marriage of a same-sex couple in a building registered under section 43A of the 1949 Act. 
In order to accommodate this change, s.26 of the Act has been amended to list the marriages that may be solemnized on the authority of superintendent registrar's certificates without any opt-in, and new ss.26A and 26B have been inserted to regulate the procedures for opting in.

For a religious organization to opt-in, written consent to the marriage of same sex couples must be given by the "relevant governing authority" ${ }^{64}$ Religious organizations other than Quakers and Jews are once again dealt with by reference to a place of worship. ${ }^{65}$ A new $\mathrm{s} .43 \mathrm{~A}$ requires separate registration of a building for the solemnization of marriages of same sex couples, in addition to the registration under s.41, but the opt-in must be exercised in writing before such registration takes place. ${ }^{66}$ Once the opt-in has been exercised, an

${ }^{64}$ In relation to the Quakers, this authority is specified in the new s.26B(3) of the 1949 Act. Clarification of the position for the different branches of Judaism is also provided in s.26B(5). For other religious organizations the governing authority is defined in s.26A(4) as "the person or persons recognized by the members of the relevant religious organization as competent for the purpose of giving consent for the purposes of this section" - a provision which may well give rise to disputes about centralization and decentralization of authority within various religious organizations (e.g. Baptists and Congregationalists).

${ }^{65}$ Section 26A of the 1949 Act.. Section 43B provides for the appointment of authorized persons to allow same sex marriages to be solemnized without the presence of a registrar. ${ }^{66}$ Once a religious organization has opted-in, the solemnization of a same-sex marriage at the residence of a housebound or detained person may take place in accordance with the rites of that organization (s.26B(6) of the 1949 Act) and a "death bed marriage" may be solemnized in accordance with those rites under s. 1 of the Marriage (Registrar General's Licence) Act 1970 
application for registration can then be made by the proprietor or trustees of the building under s.43A ${ }^{67}$ So a building will have to be registered three times if it is to be used for the solemnization of same sex marriages: once as a place of worship, once under s.41 and finally under s.43A.

There is further special provision in s.44A of the 1949 Act for the position where religious organizations are sharing a building under the Sharing of Church Buildings Act 1969. Consent of just one of those organizations to the solemnization of marriages of same sex couples is enough for the purposes of registration under s.43A, but all the sharing organizations must consent to "use" of the building for that purpose. ${ }^{68}$

The principles of the 2013 Act, excluding solemnization of same-sex marriages in accordance with the rites of the Church of England and requiring the consent of the relevant governing authority in the case of other religious organizations, are also applied to civil marriage followed by religious celebration under amendments to s.46 of the 1949 Act.

The Act contains a so called "quadruple lock" 69 to protect the position of individuals who have objections to same-sex marriage. Section 2 (1) provides, in so far as is relevant to the

${ }^{67}$ The application must be accompanied by a certificate stating that the relevant consent has been given and a copy of the consent: $\mathrm{s} .43 \mathrm{~A}(3)$.

${ }^{68}$ Section $44 \mathrm{C}$ deals with registration of shared buildings in circumstances not covered by the 1969 Act. Regulations can be made by the Secretary of State by statutory instrument to deal with this situation.

${ }^{69}$ The quadruple lock is designed to do the following:

1. Ensure that no religious organization or individual minister can be compelled to marry same-sex couples or to permit this to happen on their premises. 
present article, that a person may not be compelled by any means (including by the enforcement of a contract or a statutory or other legal requirement) to (a) undertake an opt-in activity, or (b) refrain from undertaking an opt-out activity. ${ }^{70}$ Thus, for example, a person may neither be compelled to give their consent to registration of a place of worship for the solemnization of same sex marriages, nor be prevented from cancelling a consent that has been given.

2. Provide an opt-in system for religious organization who wish to conduct marriages for same-sex couples.

3. Amend the Equality Act 2010 to reflect that no discrimination claims can be brought against religious organizations or individual ministers for refusing to marry a samesex couple.

4. Ensure that legislation will not affect the canon law of the Church of England or the Church in Wales. As a result, if either church wanted to conduct a same-sex marriage, it would require a change to primary legislation at a later date and a change to canon law.

${ }^{70}$ It also provides in s.2(2) that:

A person may not be compelled by any means (including by the enforcement of a contract or a statutory or other legal requirement) -

(a) to conduct a relevant marriage,

(b) to be present at, carry out, or otherwise participate in, a relevant marriage, or

(c) to consent to a relevant marriage being conducted,

where the reason for the person not doing that thing is that the relevant marriage concerns a same sex couple.

The protections in subs.(2) are also added to the Equality Act 2010 (s.110 and Sched.3). 
If the "lock" works, then the structure of the law for solemnization of marriages following the 2013 Act can be retained in all its complexity. If not, then the willingness of many religious organizations to offer marriages services will be curtailed and a rethink of the current structure will be inevitable.

\section{C - A COMPARATIVE SURVEY}

Given the level of complexity that rules on place of marriage have created in English law, it is worth considering how far alternative approaches to regulation exist elsewhere, and whether they operate satisfactorily, with a view to considering whether any lessons can be learned for English law.This survey is limited to the formalities of solemnization of a marriage, while recognizing that in some jurisdictions a marriage may come into existence without any particular formalities, so that the distinction between marriage and other forms of intimate relationship is not easily drawn.

It is striking that few states have, in fact, adopted or maintained an approach which regulates religious marriages by reference to a registered place of worship - although it exists in some former British colonies. ${ }^{71}$ On the other hand, French law, with its compulsory requirement of a civil ceremony, has had a strong influence on many legal systems. The development of French law was animated by the same themes that are evident with respect to

\footnotetext{
${ }^{71}$ See, for example, Uganda, Marriage Act 1904 (Cap 251) s.5 and s.22; Kenya, Marriage
} Act 1902 (Cap 150), s.7 and s.25. The relevance of these provisions depends also on the significance of customary law. In cases where the colonies were composed of emigrants seeking the religious freedom denied to them in England, it was never likely that they would adopt a law on registered places of worship intended to control dissenters. 
English law: the dynamics of the relationship between Crown, Church and State; an emerging recognition of rights of equal treatment of different religious groups; the concern of the propertied classes to control the marriages of their offspring; and a desire to ensure the accurate recording of information relating to status. While the concern for parental control is evident in the surprising proportion of articles of the Civil Code 1804 devoted to this and related issues,${ }^{72}$ it was the desire to resolve problems concerning the validity of Protestant and Jewish marriages after two centuries of religious conflict that led to discussion of civil marriage as an option, and it was the chaos in the system of civil status recording by the Catholic Church during the Revolutionary struggles that provided the immediate catalyst for reform. In the heady days of the Revolution civil marriage was endowed with quasi-religious elements, celebrating the Republic. Although many of the radical ideas of the revolutionaries in the area of family law, based on equality, were replaced by traditional, patriarchal notions in the Napoleonic Code, civil marriage remained, as a workable solution to a longstanding problem. $^{73}$

According to art. 75 of the current Civil Code, a marriage takes place at the mairie ${ }^{74}$ in front of a civil status officer. The emphasis is on ensuring that the parties understand the legal obligations into which they are entering, followed by formal declarations of consent to the

\footnotetext{
${ }^{72}$ Arts 148-160, 173-175 and 182-186

${ }^{73}$ James Traer, Marriage and the Family in Eighteenth-Century France (New York: Cornell University Press, 1980).

${ }^{74}$ In the commune where one of the parties, or one of their parents, is domiciled or has been resident for at least a month before giving notice of the marriage. Exceptions exist where there is a 'serious impediment'. The Procureur de la République can give authorization for the marriage to take place at a party's domicile or residence.
} 
marriage in front of witnesses, and the drawing up of a certificate of marriage. In general, it is well established that any religious or other personalised ceremony must be postponed until after the civil marriage. ${ }^{75}$

Many other countries also adopt the same approach as France, typically either as a result of French colonization or because of the intellectual impact of the French Civil Code, but also for ideological reasons in Communist or former Communist states. These include, for example, Belgium, the Netherlands, Switzerland, Germany, Turkey, Japan, various Latin American and West African states, Russia and China. ${ }^{76}$

At the other extreme, there are states in which the only valid form of marriage is in accordance with the parties' personal law, that being the law of their religion. This is true in some Islamic states and also notably in Israel $^{77}$ and Lebanon, states in which several religious laws co-exist but there is no provision for inter-faith marriages. In Israel there is also no provision for non-faith marriages. In Lebanon, a civil marriage between two people who had

${ }^{75}$ In fact, it is a criminal offence habitually to solemnize a religious marriage ceremony before the civil marriage has taken place: art.433-21 of the Criminal Code.

${ }^{76}$ Lynn D. Wardle, “Marriage and Religious Liberty: Comparative Law Problems and Conflict of Laws Solutions," Journal of Law \& Family Studies 12 (2010): 315.

${ }^{77}$ See, for example, the website of Hiddush, an NGO that campaigns for religious freedom and equality in Israel, accessed February 27, 2014, http://hiddush.org/subchannel-15-0Marriage.aspx. 
officially deleted any faith reference from their state records was given recognition in 2013, but the legal consequences of this remain unclear because of the absence of legislation. ${ }^{78}$

Elsewhere jurisdictions may offer both civil marriage and marriage conducted in religious or other customary form. ${ }^{79}$ The choice between a civil or a religious or customary marriage is permitted, at least in theory, in many former British colonies ${ }^{80}$ Some jurisdictions

${ }^{78}$ Dalal Mawad, "Lebanon civil marriage raises hope for change” Aljazeera, May 2, 2013, accessed Feburary 27, 2014, http://www.aljazeera.com/indepth/features/2013/04/20134309242619227.html.

${ }^{79}$ But in some countries that officially recognize civil marriages, such marriages may not be available to members of a specified confession, or may be discouraged in practice as a result of cultural traditions.

${ }^{80}$ The more complex reality is beyond the scope of this article. See for an introduction to the position in Africa, inter alia, Robert Stibich, "Family Law in Some English-Speaking African States," African Law Studies 2 (1969): 49; Sylvia Wairimu Kang'ara, "Beyond Bed and Bread: Making the African State Through Marriage Law Reform - Constitutive and Transformative Influences of Anglo-American Legal Thought," Comparative Law Review 3 (2012): 1.2, accessed January 6, 2014, http://www.comparativelawreview.com/ojs/index.php/CoLR/issue/archive. In mass emigration destinations, including the USA, Canada, and Australia, the extermination or marginalization of indigenous populations has had the effect that the status of customary marriages provoked little debate until recent decades with the rise in respect for the rights of indigenous peoples. Customary marriages between members of recognized Native American tribes are certainly recognized in the United States (Montana v. United States, 450 U.S. 544, 564 (1980). See also U.S. v. Jarvison, 409 F.3d 1221, 1225 (10th Cir. 2005)) but the picture 
strongly influenced in other respects by French or German law have retained the option between civil marriage at the relevant civil status office and religious marriage. Originally this occurred if the Catholic Church or another national church held a position of strength there. ${ }^{81}$ More recently, a wider range of marriages in religious form have been granted recognition in some states. This can by illustrated by examining the position in Spain, ${ }^{82}$ Sweden ${ }^{83}$ and Scotland - jurisdictions which adopt distinctly different approaches.

in Canada is less certain (see Bradford W. Morse, "Indian and Inuit Family Law and the Canadian Legal System," Am. Indian L. Rev. 8 (1980): 199) and aboriginal marriages are not recognized as such in Australia (see the Report of the Australian Law Reform Commission on the Recognition of Aboriginal Customary Laws (ALRC Report 31), Part 12). Recognition of common law marriages - or the protection afforded to cohabitants - nevertheless reduces the harshness of this stance in many cases.

${ }^{81}$ See also Norman Doe, Law and Religion in Europe: A comparative introduction, (OUP, 2011), pp 216-222, who highlights a third model whereby Roman Catholic marriages are recognized as having civil effect from the time of their ritual celebration, whereas marriages solemnized by ministers of other faith communities are regarded as civil marriages solemnized in a religious context, and are formed on subsequent civil registration. ${ }^{82}$ See Zoila Combalía and María Roca, "Religion and the Secular State in Spain," in Religion and the Secular State: Interim Reports, prepared for the XVIIIth International Congress of Comparative Law, held 25 - 31 July 2010 in Washington, D.C. 632-634 and 639640, accessed February 27, 2014, http://www.iclrs.org/content/blurb/files/Spain.2a.pdf.

${ }^{83}$ In Sweden, the Lutheran Church was the established church until 2000. See Maarit JänteräJareborg, "National Report for Sweden," in Religion and the Secular State: Interim Reports, prepared for the XVIIIth International Congress of Comparative Law, held 25 - 31 July 2010 
The most restrictive approach is found in Spain. ${ }^{84}$ Article 81 of the Spanish Constitution makes provision for the implementation of fundamental rights and freedoms through Organic Acts. Organic Act 7/1980 of 5 July of Religious Freedom was passed to implement the fundamental right of religious freedom. Under it, religious confessions that have "well recognized roots" in Spain can enter into an agreement with the State, modeled on the comparable agreements which have long regulated the relationship of the Spanish State with the Catholic Church. The recognized confessions are Protestants, Jews and Muslims (each of which has had to form an umbrella organization for its various constituent groups in order to enter into the agreement). Their agreements were signed on November 10, 1992, and as a consequence the civil validity of marriage ceremonies performed by each confession is recognized in Spain. ${ }^{85}$ By way of example, the agreement with the Protestant confession

in Washington, D.C. 682-683, accessed February 27, 2014, http://www.iclrs.org/content/blurb/files/Sweden.1.pdf.

${ }^{84}$ Reforms have been proposed that would liberalize the position considerably, but they formed part of a package of measures on non-contentious jurisdiction that was rejected by the Spanish Parliament on December 11, 2014.

${ }^{85}$ Combalia and Roca, "Religion and the Secular State in Spain," 632-634 and 639-640. The arrangements under the agreements are different from those applying to the Catholic Church in that it is necessary to obtain a certificate of capacity from the civil authorities in advance of the marriage. Furthermore the agreements require the marriage to take place before the minister of religión in the presence of two witnesses, irrespective of whether the religious law in question has similar requirements. 
provides that a marriage will be recognized if it is performed "before the minister of religion officiating at the ceremony". ${ }^{86}$

The Swedish Constitution allows a greater degree of flexibility. The free exercise of religion is made possible via the "Ordinance of Government" (Regeringsformen). The Ordinance includes the possibility for the State to delegate to religious communities certain state functions, and notable the solemnization of marriage. ${ }^{87}$ Since January 1, 2000, the law has provided a new procedure for the legal recognition of registered denominations. The State agency that processes applications for recognition (the Kammarkollegiet) also deals with the State's delegations to denominations regarding the right to officiate marriage ceremonies. In each case the denomination must have at least 3,000 members and its activities must be organized such that it can be expected to pay regard to the rules of the Swedish Marriage Code. According to Jänterä-Jareborg, in 2008 approximately forty registered religious communities in Sweden had authorization to officiate at marriage ceremonies in Sweden. ${ }^{88}$

${ }^{86}$ Pedro Luis García Callejón, “El Matrimonio Religioso No Católico Ante El Derecho Español” (Universidad de Córdoba, Servicio de Publicaciones, 1993): 27. The arrangements under the agreements are different from those applying to the Catholic Church in that it is necessary to obtain a certificate of capacity from the civil authorities in advance of the marriage.

${ }^{87}$ Implemented by Law 305 of 1993 on the Right to Officiate Marriages Within Religious Communities.

${ }^{88}$ Jänterä-Jareborg, "Religion and the Secular State in Sweden," 682-683. She also notes that when same sex marriage was authorized in Sweden in 2009, it was considered that the various denominations should decide for themselves whether or not to offer such marriages. To impose a state requirement would interfere with freedom of religion. Indeed, the various 
Scotland takes a more liberal approach again. Although civil marriages are regulated in a similar way to those in England, the position in relation to religious marriages is quite different. Under the Marriage (Scotland) Act 1977 marriages can be solemnized by representatives of recognized religious bodies. These include a minister of the Church of Scotland, or a minister, clergyman, pastor, or priest of a religious body, or a person recognized by a religious body as entitled to solemnize marriages on its behalf. ${ }^{89}$ Temporary registration of a celebrant is also possible under s.12 of the Act. It is the person, and their status as part of a recognized organization, that is relevant - not the place of solemnization.

These provisions have been used to approve marriage celebrants from a wide range of religious bodies. ${ }^{90}$ Prior to recent amendments, they were also relied on to permit the authorization of humanist celebrants. ${ }^{91}$ In 2005, Scotland's Registrar General concluded that

religious denominations may impose other conditions on their willingness to solemnize marriages, such as a requirement that both parties to the marriage are members of that denomination.

${ }^{89}$ Sections 8 of the Marriage (Scotland) Act 1977 (the 1977 Act) differentiates between prescribed religious bodies (see the Marriage (Prescription of Religious Bodies) Regulations 1977 SI 1977/1670), and those that are not prescribed, but in effect any religious body defined in s.26(2) of the 1977 Act as "an organized group of people meeting regularly for common religious worship" - can nominate a celebrant (s.9). See further Joe Thomson, Family Law in Scotland (London: Bloomsbury Professional, 2011), 14.

${ }^{90}$ Disparaging reference was made during the debates on the Marriage (Same Sex Couples) Act 2013 to marriages in Scotland by members of the White Eagle Lodge, by pagans and by members of the National Union of Spiritualists.

${ }^{91}$ Temporary authorization under s. 12 of the Act. 
he was required to interpret the legislation in a way that was consistent with the European Convention on Human Rights, and that giving binding force to religious weddings but not to humanist ones might contravene the right to freedom of thought, conscience and religion under s.9 of that Convention, which includes non-religious belief. ${ }^{92}$ The Marriage and Civil Partnership (Scotland) Act 2014 (the 2014 Act), has now amended the 1977 Act to refer to a "religious or belief body" rather than a religious body. ${ }^{93}$

The possibility of registration of a temporary celebrant has somewhat blurred the lines between recognition of a religious or belief body and recognition of individual applicants, ${ }^{94}$ but s.14 of the 2014 Act clarifies the fact that such a celebrant must be a member of a religious or belief body.

Furthermore, the Scottish legislature has also taken the opportunity in the 2014 Act to respond to public concerns about the need for celebrants to come from responsible organizations by including a requirement that recognized religious or belief bodies should

92 "Pair tie knot at humanist wedding," BBC News, June 18, 2005, accessed January 10, 2014, http://news.bbc.co.uk/1/hi/uk/4102310.stm.

${ }^{93}$ Sections $11-12$ and 22 of the 2014 Act.

${ }^{94}$ Guidance provided on the National Records of Scotland website, on the question of whether it is possible for a family friend to solemnize a marriage, states: "If it is a religious marriage (which includes other belief systems) you are planning and your family friend is not already authorised to act as a celebrant, the Registrar General can grant a temporary authorisation for a particular marriage. A temporary authorisation can only be granted to someone who is affiliated to a religious body and who is supported by office bearers of that body or other belief system to conduct a marriage ceremony on its behalf." (http://www.nrscotland.gov.uk/registration/getting-married-in-scotland) 
meet certain "qualifying requirements". ${ }^{95}$ Consultation on such qualifying requirements is due to take place in 2015, but an initial discussion paper (hereafter, the Discussion Paper) was issued in July $2014 .{ }^{96}$ According to that paper there are four main reasons behind the proposed introduction of qualifying requirements: (i) To ensure the continued reputation, dignity and solemnity of marriage and civil partnership ceremonies in Scotland; (ii) To combat sham marriages and civil partnerships, which are designed to avoid UK immigration controls; (iii) To combat forced marriages, and (iv) To ensure that marriage and civil partnership ceremonies are not carried out for profit or gain. ${ }^{97}$ These concerns will be considered further in Sections D and E.

In contrast to English law, Scots law is very liberal as to the location of weddings. A religious or belief wedding may take place anywhere that the celebrant will agree to. A civil wedding can be held in a registration office or in any of a list of approved places - but it is also possible to apply for "temporary approval" of a desired location.

In each of the above examples - Spain, Sweden and Scotland - it is the religious organization that is recognized. The status of the celebrant as part of that organization ensures the validity of the marriage. An alternative approach is to authorize individual celebrants to

${ }^{95}$ Hannah Johnson and Heather Lyall, SPICe Briefing SB 13-51: Marriage and Civil Partnership (Scotland) Bill, November 25, 2013. The 2014 Act does not, however, specify these qualifying requirements but stipulates that they may be set out in regulations made by the Scottish Ministers.

${ }^{96}$ Marriage And Civil Partnership (Scotland) Act 2014, The Qualifying Requirements: An Initial Paper, available at 〈http://www.scotland.gov.uk/resource/0045/00459045.pdf $>$ Accessed December 30, 2014.

${ }^{97}$ See further below at 62 . 
solemnize marriages. This approach is adopted, to a greater or lesser extent, in e.g. the US, Canada, Australia and New Zealand. ${ }^{98}$ In each case a mixture of approaches applies, with authorization of individual celebrants being one just one of the available methods of regulation.

In the United States marriage regulation is a matter for State, rather than Federal, laws. The authority to solemnize marriages is typically conferred on judges or retired judges, ${ }^{99}$ ministers of religion, and often also a variety of civic authorities. Some states also provide for the authorization of a marriage celebrant for one day, so that a member of the family or a friend of one of the intending spouses can officiate, ${ }^{100}$ or even allow "self-marriage". ${ }^{101}$ The concept of "minister of religion" has provoked considerable difficulties. The definition of religion is a constitutional issue in the United States, since the First Amendment mandates the separation of church and state and the free exercise of religion. From at least the 1960s the concept has been given a broad, non-theistic definition. A footnote to the Supreme Court judgment in Torcaso v. Watkins ${ }^{102}$ states: “Among religions in this country which do not

98 Jurisdiction to regulate marriage is allocated to the Federation in Australia, but at state and provincial level in the US and Canada.

${ }^{99}$ Often of specified courts.

${ }^{100}$ Cal. Fam. Code, $§ 401$ (a) and (b); Mass. Gen. Laws Ch. 207, §.39.

${ }^{101}$ Colorado Revised Statutes 14-2-109 (1) provides that "a marriage may be solemnized ... by the parties themselves", but the informal approach to marriage accepted in Colorado is also demonstrated by the fact that it recognizes common law marriage where the parties cohabit, mutually agree to be married, and openly hold themselves out to the public as married (People v. Lucero, 747 P.2d 660 (Colo. 1987)).

102367 U.S. 488 (1961), fn 11. Key US Supreme Court decisions contributing to the jurisprudence on the meaning of religion include United States v. Seeger, 380 U.S. 163 
teach what would generally be considered a belief in the existence of God are Buddhism, Taoism, Ethical Culture, Secular Humanism and others".

Against that background, the Humanist Society and other atheist and humanist organizations offer ordination for non-theist ministers, and such ministers are accepted as marriage celebrants in some States but not in others. ${ }^{103}$ Some States even accept as celebrants ministers from the Universal Life Church (ULC), which offers ordination online with no fee and no criteria to be satisfied. ${ }^{104}$ In discussing whether such "ministers" should be authorized,

(1965), and Welsh v. United States, 398 U.S. 333 (1970). The concurring opinion of Adams CJ in Malnak v. Yogi, 592 F.2d 197 ( $3^{\text {rd }}$ Circ. 1979) has also been influential and was critiqued by the Supreme Court in Regina (Hodkin and another) v. Registrar General for Births, Deaths and Marriages.

${ }^{103}$ See for example Amanda Greene, "Humanists find ways to say 'I do' without God” Religion News Service, May 17, 2013, accessed September 30, 2013, http://www.religionnews.com/2013/05/17/humanists-find-ways-to-say-i-do-without-god/. A narrow view of the concept of minister of a religious denomination was taken in Washington DC, but the law has recently been changed to allow civil celebrants to officiate (the Marriage Officiant Amendment Act of 2013).

${ }^{104}$ For details see Robert E. Rains, "Marriage in the Time of Internet Ministers: I Now Pronounce You Married, But Who Am I To Do So?” University of Miami Law Review 64 (2010): 809. In November 2012, a federal judge in Indiana refused a request by the atheist Center for Inquiry for expansion of the category of persons authorized to solemnize marriages, stating that a variety of avenues existed which permitted secular celebrants to play a role in marriage ceremonies, including ordination as a member of the Universal Life Church: see David Edwards, "Federal judge rules atheists must become 'clergy' to perform 
several US courts have focused not on the scope of the right to exercise a religious belief but rather on the state's control over the regulation of marriage. Being a minister of religion can thus be considered as a threshold test. This can be illustrated by the assertion of the Virginia Supreme Court in Cranmer v Commonwealth that the state has the "necessity that the marriage contract itself be memorialized in writing ... by a person of responsibility and integrity and by one possessed of some educational qualifications."

A recent New York decision adopts a different focus, commenting on "the inexorable trend toward marriages conducted by friends or relatives of a couple who have been ordained as ministers by internet churches". The court goes on to add that getting married is a serious decision with wide ranging consequences and emphasizes the importance of obtaining a wedding license.

"It is easy to understand why couples might choose a friend or relative, rather than a judge or religious figure whom they have only just met, to play an important part in a hugely personal and momentous occasion. But to be able to dispense altogether with the legal requirements imposed by the State of New York makes the process too easy and robs it of the seriousness that is warranted in view of the responsibilities and obligations that marriage entails. With fewer and fewer marriages being performed

marriages," The Raw Story, December 3, 2012, accessed January 7, 2014, http://www.rawstory.com/rs/2012/12/03/federal-judge-rules-atheists-must-become-clergy-toperform-marriages/.

105202 S.E.2d 911 (Va. 1974), cited in Rains, "Marriage in the Time of Internet Ministers," 821. 
with the attendant ritual and weight of a traditional religious practice, the reason for requiring a marriage license is that much more compelling." 106

The concept of "minister of religion" is also contested in some Provinces in Canada. The Humanist Association of Canada is a recognized religious denomination in Ontario, and its appointed officiants may be licensed by the Province, but an application by the British Columbia Humanist Association to register religious representatives was recently rejected. ${ }^{107}$ A similar range of approaches, from conservative to more liberal, can be found in respect of the persons licensed to solemnize civil marriages. In British Columbia, for example, the post of Marriage Commissioner is from time to time advertised by the government and appointments are made from respected members of the community, who must also be retired from their previous employment. In Quebec, the range of possible officiants is found in art.366 of the Civil Code. Marriages may be solemnized by clerks and deputy clerks of the Superior Court who have been designated for that purpose, notaries, mayors, members of

106 Ponorovskaya v Stecklow 2014 NY Slip Op 24140 Decided on May 29, 2014 Supreme Court, New York County. Cooper J comments on the conflict between different departments of the New York Appellate Division on the question of validity of marriages performed by ULC celebrants (Ranieri v Ranieri, 146 AD2d 34 (2d Dept 1989), adopting the reasoning in Ravenal v Ravenal, 72 Misc 2d 100, 102 (Sup Ct, NY County 1972) and Oswald v Oswald, 107 AD3d 45, 48 (3d Dept 2013), but is able to decide the case on a point of private international law.

${ }^{107}$ See their press release of February 20, 2013, accessed January 7, 2014, <http://bchumanist.ca/attachments/article/100/Press\%20Release\%20\%20Officiant\%20Rejection.pdf. 
municipal or borough councils and municipal officers designated by the Minister of Justice. A marriage may also be solemnized by a person who is temporarily designated as an officiant - so that the parties can select someone who is special to them. ${ }^{108}$

A more general process of liberalization can be found in New Zealand and Australia. In New Zealand, the Marriage Act $1955^{109}$ ss. 8 ff. permits ministers of specified religions, ${ }^{110}$ nominees of approved organizations - where the principal object or one of the principal objects of the organization is to uphold or promote religious beliefs or philosophical or humanitarian convictions - and other "persons of good character", in particular Justices of the Peace, to be registered as marriage celebrants. Further conditions for registration of individual applicants are that the applicant will conscientiously perform the duties of a marriage celebrant under this Act and under the Births, Deaths, Marriages, and Relationships Registration Act 1995; and that it is in the interests of the public generally, or of a particular community (whether defined by geography, interest, belief, or some other factor) that the person in question be a marriage celebrant.

In Australia ${ }^{111}$ there are three categories of persons who can solemnize marriages: ministers of a recognized religion, civil status officers for each State or Territory, and

${ }^{108}$ See the website Justice Québec, accessed January 7, 2014, http://www.justice.gouv.qc.ca/english/publications/generale/celebrant-a.htm. The relevant provisions on marriage officiants are found in art.366 of the Quebec Civil Code and in the Rules respecting the solemnization of marriages and civil unions.

${ }^{109}$ As amended by the Marriage Amendment Act 2010.

${ }^{110}$ Specified in Sch. 1 to the 1955 Act.

${ }^{111}$ For further details on Australian marriage law see e.g. John Neville Turner, “Australia,” in International Encyclopaedia of Family and Succession Law, ed. Walter Pintens (Kluwer 
"marriage celebrants" - who may in effect be any fit and proper person with the necessary skills who seeks registration as a celebrant. ${ }^{112}$ Some concerns have been expressed about over supply to the market for celebrants and lack of proper training. ${ }^{113}$ The Attorney General's Department, which is responsible for regulation of marriage celebrants, is therefore implementing various reforms to enhance training, regulation and ongoing professional development. ${ }^{114}$ A significantly enhanced training requirement was introduced from $2010 .{ }^{115}$

Law International, 1997), 24: "In Australia, it is ridiculously easy to get married - there are virtually no formalities, and such as exist are regarded as directory, not mandatory. A marriage may be celebrated in any place and at any time ..."

${ }^{112}$ Section 39C of the Marriage Act 1961 deals with entitlement to be registered as a marriage celebrant and establishes a list of criteria.

${ }^{113}$ Responses to a consultation by the Attorney General's Department. See the summary of feedback, accessed February 28, 2014, http://www.ag.gov.au/FamiliesAndMarriage/Marriage/Pages/ChangestotheMarriageCelebran tsProgram.aspx. See also, David Humphries, "I do, I do ... but unfortunately some marriage celebrants don't," The Sydney Morning Herald, December 10, 2011, accessed January 8, 2014, http://www.smh.com.au/lifestyle/weddings/i-do-i-do-8230-but-unfortunately-somemarriage-celebrants-dont-20111209-1onnm.html.

${ }^{114}$ See further the website of the Attorney General's Department (http://www.ag.gov.au). ${ }^{115}$ A Certificate IV in Celebrancy is required, a 13 unit certificate with 5 core and 8 elective modules. One of the major providers of this qualification offers it across seven two-day training sessions, with assessments in between (see the AssentTECS website at http://www.assenttecs.com.au). Five hours of Ongoing Professional Development training is also required each year. 
In addition, a policy of cost recovery in relation to the services provided to marriage celebrants ${ }^{116}$ has meant the introduction of an initial registration application fee and an annual registration charge. ${ }^{117}$ There are thus disincentives to becoming a celebrant for anyone who does not intend to take it seriously and to conduct a significant number of ceremonies.

Comparison with other jurisdictions thus suggests that the approach to regulation of marriage under English law is unusual, and unusually complex. Many jurisdictions have a far more inflexible approach, recognizing only civil marriage. This takes place in the civil status or vital statistics offices for the residence of one of the parties, although some variation exists, and there seems to be a move towards privatization of civil status functions, with the result that notaries (in particular) are acquiring new marriage celebrating and divorce granting competences in some civil law jurisdictions. Where marriage in religious form is also recognized as having civil effects, it is typically the religious body that is authorized to

116 These services include assessing and authorising new marriage celebrants for registration, reviewing celebrant performance, resolving complaints about celebrants, handling a large volume of enquiries from celebrants, producing information and guidance materials, managing ongoing professional development arrangements for celebrants and engaging with celebrants and their peak group. When the Marriage Celebrants Program was launched in 1973 less than two percent of couples chose a civil ceremony. Now over 70 percent of marriage ceremonies in Australia are civil ones, and there are about 10,500 Commonwealthregistered marriage celebrants administered by the Program: see the Explanatory Memorandum to the Marriage Amendment (Celebrant Administration and Fees) Bill 2014. 117 These have been introduced by the Marriage (Celebrant Registration Charge) Act 2014 and the Marriage Amendment (Celebrant Administration and Fees) Act 2014 respectively. 
solemnize marriages in accordance with its rites: the place of solemnization is a matter for ritual laws. Alternatively non-religious organizations or individual celebrants may be authorized. This approach has been adopted in several common law jurisdictions - with varying degrees of regulation of celebrants, including the authorization as celebrant of a friend of the couple getting married, or an 'internet minister'.

\section{D - RECENT ATTEMPTS AT LAW REFORM}

The above historical and comparative tours demonstrate how the English law focus on place of worship is a product of its history of church-state relations coupled with registration requirements arising out of past religious discrimination, ${ }^{118}$ and that the trend in countries which do not have a compulsory civil ceremony before a civil status official is towards allowing couples greater freedom of choice as to the celebrant - who may be required to meet certain performance standards. But the regulation of marriage is a subject that excites passions, and where there are strong conflicts of view that make any change to the law difficult. ${ }^{119}$

Compulsory solemnization by civil status officials and a system of licensed celebrants or officiants have both been considered for adoption in England. Indeed uniform civil preliminaries, rather than Church of England banns and licenses, have been proposed ever

118 The speech of Lord Wilson in R. (Hodkin and another) $v$ Registrar General of Births, Deaths and Marriages explains how a requirement that was originally discriminatory in fact became a "source of valuable privileges" as it became associated with various tax exemptions.

${ }^{119}$ Most recently apparent in the debates on the Marriage (Same-Sex Couples) Act 2013. 
since the reforms of $1836 .{ }^{120}$ There is nevertheless little indication of enthusiasm for mandatory civil marriage, following the French model. A Law Commission Working Party noted in 1973 that

[t]he introduction of such a system would have the advantages that flow from uniformity in arrangements for the solemnisation of marriage; nevertheless, it was our impression, when we issued the Working Paper, that it would not be generally acceptable unless, at any rate, no other satisfactory method of improving the present arrangements was possible. Consultation has not altered this impression. ${ }^{121}$

${ }^{120}$ Until recently that proposal had been resisted successfully by the Church (see Cretney, Family Law in the Twentieth Century, $9 \mathrm{ff}$.) but a breach has been made in the control of the Church over those preliminaries by the Immigration Act 2014. As a result of concerns over sham marriages, s.57 of the 2014 Act has strictly limited the possibility of marriage after the publication of banns in cases where "one or both of the persons whose marriage is to be solemnized is not a relevant national" (that is, British, EEA or Swiss nationals). Instead the civil preliminaries will be required in such cases.

121 Report of the Joint Working Party of the Law Commission and the Registrar General, Law Commission, Solemnisation of Marriage in England and Wales (Law Com No.53, 1973), Annex para.72. 
Views were expressed both for and against this position when the issue arose tangentially during the debates on the Marriage (Same Sex Couples) Bill. ${ }^{122}$

A celebrant model was also identified as a possibility in the 1973 Law Commission Report. ${ }^{123}$ But in the end, the Law Commission was simply unable to reach agreement on the central issue of the conduct of the marriage ceremony:

Some of us take the view that if the preliminaries laid down by the law are complied with, and if there is present at the wedding at least one person qualified to supervise the solemnisation of the marriage and see that it is duly registered then the law need require no more and that the actual place where or time when the marriage is solemnised is unimportant. Others share the view of the Working Party that all marriages should be celebrated at a place prescribed by law within permitted hours, subject to the discretionary powers of the Archbishop of Canterbury and the Registrar General to deal with exceptional cases. We are ... content to express the different views in the hope that others may continue the discussion and arrive at an agreed basis for legislation. ${ }^{124}$

This celebrant model was actively pursued during the period 1999-2004, starting with the publication by the Registrar General for England and Wales of a consultation paper on

${ }^{122}$ For: Simon Hughes (HC Deb 21 May 2013 col 1104); against: Baroness Brinton (HL Deb 19 Jun $2013 \operatorname{col} 299)$.

123 The reference to the presence of "at least one person qualified to supervise the solemnisation of the marriage and see that it is duly registered".

${ }^{124}$ Law Commission, Solemnisation of Marriage, 7. 
modernizing the registration service. ${ }^{125}$ As a result of the consultation, a White Paper on Civil Registration: Vital Change was published in $2002,{ }^{126}$ which among other things proposed a move to a celebrant system, influenced by the laws discussed above and in particular those of Scotland, Australia and New Zealand. Some flesh was given to the proposals, ${ }^{127}$ and the intention was to implement them in stages via Regulatory Reform Orders under the Regulatory Reform Act 2001. But when the first draft Order, concerning the registration of births and deaths, was laid before Parliament in 2004, the House of Commons Regulatory Reform Select Committee and the House of Lords Delegated Powers and Regulatory Reform Committee recommended that the order-making power under the Regulatory Reform Act 2001 should not be used, notably because the proposed measures could not be described as uncontroversial. ${ }^{128}$ No steps were taken to bring forward the primary legislation that would otherwise be required. ${ }^{129}$

${ }^{125}$ Civil Registration: Modernising a Vital Service (Treasury consultation paper, 1999)

${ }^{126}$ Office for National Statistics (Cm 5355, 2002).

${ }^{127}$ See in particular, General Register Office, Civil Registration: Delivering Vital Change (Regulatory Reform Order consultation document, 2003).

${ }^{128}$ Regulatory Reform Committee, Proposal for the Regulatory Reform (Registration of Births and Deaths) (England and Wales) Order 2004 (HC 2004-2005, 118); Delegated Powers and Regulatory Reform Committee, Proposal for the draft Regulatory Reform (Registration of Births and Deaths) (England and Wales) Order 2004 (HL 2004-2005, 14). ${ }^{129}$ Digitization of civil registration records with the ultimate objective of providing online access to such records has proceeded under existing legislation. See, for further details to 2010, the Parliamentary Briefing Paper "Digitisation of Civil Registration Records" Standard Note SN/HA/3709, accessed February 23, 2014, www.parliament.uk/briefing- 
A more limited proposal extending the range of options for the celebration of marriage was raised in a Private Member's Bill in $2012^{130}$ and then during the passage of the Marriage (Same-Sex Couples) Act. Amendments were formulated by the British Humanist Society. ${ }^{131}$ At first a proposal was made to create a category of "approved organizations"132 which would be subject to the same regulation as Jews and Quakers. This proposal was not accepted in the Public Bill Committee, following the view expressed by the Parliamentary Under-Secretary of State for Women and Equalities that the Government could not support the amendment because it involved structural change to the rules governing the solemnities of marriage which went well beyond the limited purposes of the Bill, placed a difficult burden on the Registrar General in deciding which organizations should be approved, and risked undermining the quadruple lock. After various consultations, a new amendment specifically identifying humanists was proposed at the Report Stage in the House of Commons, but was withdrawn again on the basis of an assessment by the Attorney-General that it was not compatible with the Human Rights Act 1998 as prioritizing one non-religious belief

papers/sn03709.pdf. The project was paused in September 2010 and there are currently no plans to continue it.

${ }^{130}$ Marriage (Approved Organisations) Bill [HL] 2012-13.

${ }^{131}$ See Marriage (Same Sex Couples) Bill PBC 12 March 2013, Col 468 - 477. Although it was recognized that humanists could have the wedding ceremony of their choice following a civil marriage, the argument for changing the law was based on the fact that religious organizations could solemnize marriages without the disruption of two separate ceremonies, and on the increasing popularity of humanist ceremonies.

132 To be approved by the Registrar General. 
organization over another. ${ }^{133}$ As a compromise, the 2013 Act provides, in s.14(4) that "the Secretary of State may by order make provision for and in connection with permitting marriages according to the usages of belief organizations to be solemnized on the authority of certificates of a superintendent registrar". Section 14(1) requires the Secretary of State to arrange for a review as to whether such an order should be made, and if so the form it should take. Consultation was undertaken in July to September 2014 and the results were published, along with the Government's response (hereafter, the 2014 Consultation Response), on December 18, 2014. ${ }^{134}$

The aim of the consultation was "to seek views on whether there is a substantial case for permitting legally valid marriage ceremonies for those of humanist belief and potentially other non-religious belief, or whether the current approach should remain." There were also further questions as to the organizations that might fall within the s.14 definition of a belief organization as "an organization whose principal or sole purpose is the advancement of a system of non-religious beliefs which relate to morality or ethics"; the locations in which valid belief marriage ceremonies should be allowed to take place; and any safeguards that should be put in place.

It was clear that the majority of those responding to the consultation were connected to the British Humanists Association, and had made use of a standard form response to the consultation. They were in favor of the law being changed to allow valid belief marriage ceremonies, arguing that the current law is discriminatory since it does not allow them to

${ }^{133}$ HC Deb 21 May 2013, col 1071 -1122 .The position of Quakers and Jews was justified as ante-dating the 1998 Human Rights Act.

${ }^{134}$ Ministry of Justice, Marriages by Non-Religious Belief Organisations: Summary of Written Responses to the Consultation and Government Response (2014). 
marry in a legal ceremony rooted in their beliefs conducted by a person who shares those beliefs, or in a place that is personally meaningful to them. They took the view that there should be no restriction on available locations for the ceremony, including outdoors, since the important criterion was the meaning attached to the place by the parties. Respondents who opposed a change in the law were particularly concerned about the risk of relaxed regulation leading to more forced and sham marriages and inappropriate ceremonies. In addition, local registration services offered the opinion that the demand from couples was for outdoor marriages rather than belief ceremonies.

On consideration of the responses, the Government has concluded that it is not possible to implement changes in the law of marriage to accommodate belief organizations without further review. Equality issues predominate. Allowing belief marriages at unrestricted locations creates an inequality for the majority of religious groups and couples who are restricted to their church or registered place of worship; qualifying tests for organizations permitted to celebrate marriages are difficult to formulate in a way that is not discriminatory - both in terms of determining the definition of a "belief organization" and in terms of the parallel treatment of religious and belief organizations. The order making power under s.14 of the 2013 Act, is insufficient to permit the wider changes in the law needed to deal with these issues.

"[T]here is no option which we think can be implemented immediately which would provide for complete equality of treatment between those who have religious beliefs, those with humanist or other non-religious beliefs, and couples more generally."135

\footnotetext{
${ }^{135}$ Ibid. at para. 46.
} 
The Law Commission is therefore being asked to review the law concerning marriage ceremonies with a view to more comprehensive reforms. Whether any Law Commission proposals will finally be adopted as legislation is, of course, a different matter - but given the issues raised by the Consultation Response and the emphasis on equality issues, it is difficult to see how rules structured around a registered place of worship could survive.

\section{F - THE FUTURE OF MARRIAGE SOLEMNIZATION}

At the time of Lord Hardwicke's Act, three interests significantly coincided: the interest of the state in providing some certainty as to who was married and avoiding clandestine marriages through the publicity of a church wedding; the interest of the Anglican Church in celebrating the sacrament of matrimony and reinforcing its position in society; and the interest of the couple in obtaining God's blessing on their new life together. But the picture has changed. New ways exist of obtaining a reliable record of civil status. Clandestine marriage is no longer a significant concern. Church congregations have dwindled and with them the Christian significance of marriage. What are the modern drivers shaping any reform of the law on solemnization of marriages?

\section{(i) The interests of the couple}

Writing with specific reference to the United States, Andrew Cherlin has argued that although the practical importance of marriage has declined, its "symbolic" importance has increased. ${ }^{136}$ "Whereas marriage used to be the foundation of adult family life, now it is often

${ }^{136}$ Andrew J. Cherlin, The Marriage-Go-Round: The State of Marriage and the Family in America Today (Vintage Books, 2010) Ch.5. 
the capstone ... Being married is less of a social role and more of an individual achievement - a symbol of successful self-development." This may be particularly true of America, but it also reflects to some extent developments in Britain. Marriage may not, in general, be held in such high regard - but it is increasingly postponed until a couple have achieved personal and job security and can afford to celebrate their relationship in style. This symbolic value can also be seen in the campaign for same sex marriage: it was not about obtaining rights, for they could already be acquired through civil partnership. Rather it was about celebrating a loving and committed relationship, and enjoying status and esteem equal to that of heterosexual married couples.

A wedding is a couple's "celebrity moment", and this creates the incentive to plan an individualized event. The trend in this direction can be seen in celebrant advertising of services tailored to the requirements of the parties. It is seen in the rise of weddings abroad and television shows that celebrate the variety of weddings. It is reflected in the desire of a bride and groom to ask a family member or friend to officiate. And it is seen in the insistence by members of the British Humanist Association in the 2014 Consultation Response that it should be possible to get married at a place that has "personal meaning". The 2014 Consultation Response notes that many people who are not religious have spiritual beliefs that they would like reflected in a wedding ceremony, and that some might want multi-faith elements. The law currently has no way of accommodating these desires. Moreover, media representations of marriages in a variety of forms and locations foster dissatisfaction with the more restrictive rules of English law.

From the couple's perspective, the logical way forward is the removal of obstacles to their free expression of their individualism.

(ii) The interest of the state 
Rains concludes, after his survey of US laws on the regulation of marriage celebrants:

Today, it is difficult to perceive of a valid and enforceable reason for the state to demand a particular marriage methodology for the couple who have obtained a license ensuring their eligibility and intent to marry, as long as the fact of their marriage is then duly registered with the state. The state may validly regulate who may enter into marriage ... and enforce those rules by a licensure requirement. The state may validly require registration of the marriage for recordkeeping purposes. But the day is simply over that the state can meaningfully regulate who may officiate when the couple signify their present-tense declaration of entry into marriage, or even require any officiant other than the couple themselves. ${ }^{137}$

Nevertheless, in the United Kingdom, the state does claim some residual interest in the regulation of such formalities. Three reasons for this can be argued: (a) an officiant may be best placed to detect if there is some element of fraud or duress involved in the marriage and thus to assist the state in policing access to residence and nationality and preventing forced

${ }^{137}$ Rains, "Marriage in a Time of Internet Ministers," 840-841. See also Stephen Cretney, Family Law in the Twentieth Century, 9: "The 1836 Act was based on a very clear analysis of the respective interests of church and state in marriage. The state had a proper interest in preventing clandestine marriages and in being able to determine whether or not a person was married, with all the legal consequences which followed from that status; and the state was therefore entitled to insist on a universal and efficient system for the registration of marriages. But so far as the actual celebration of the marriage, the states concern was limited to ensuring that the ceremony be recognised by both parties as binding." 
marriages; (b) there may be a desire to control quality; ${ }^{138}$ (c) different marriage models have different resource implications for the state.

(a) Policing marriage

Current levels of media hysteria and government concern about sham marriage ${ }^{139}$ and forced marriages, in the UK and other EU Member States, seem indicative of moral panic rather than a reasoned response to the data. Nevertheless, there is clear evidence that marriages of convenience are regularly arranged for immigration purposes and that this an area in which organized crime groups are active, and which may also involve human trafficking. ${ }^{140}$ And whether the number of forced marriages is large or small, this is a phenomenon which needs to be taken seriously and handled sensitively.

In the United Kingdom, an increasing focus is being placed on the need for thorough preliminaries in order to detect sham marriages, but both civil and religious preliminaries have been found wanting in this regard. ${ }^{141}$ The Government had sought to control such

${ }^{138}$ See generally above at pp.36-45.

${ }^{139}$ For a definition of the concept see the Immigration and Asylum Act 1999 s.24(5).

${ }^{140}$ Europol Early Warning Notification 2014/8.

${ }^{141}$ As a result of several egregious examples of clergymen solemnizing multiple sham marriages, in 2011, the Church of England House of Bishops issued new guidance on the marriage of persons from outside the EEA, recommending that such a marriage should not be preceded by banns but rather a common license should be obtained, and that more stringent procedures and checks should be implemented. This initiative has now been replaced by the provisions in the Immigration Act 2014. 
marriages through the requirement of a Certificate of Approval, first introduced in 2005, ${ }^{142}$ whereby a fee was payable, and the applicant had to have sufficient leave to remain in the UK before qualifying for the certificate. ${ }^{143}$ The scheme was challenged under, inter alia, Arts 12 and 14 ECHR. It was found to be in breach of those provisions in the national courts ${ }^{144}$ and before the European Court of Human Rights ${ }^{145}$ and during the course of the proceedings was modified and eventually withdrawn.

Nevertheless, the European Court of Human Rights specifically noted that:

$[I] n$ the context of immigration laws and for justified reasons, the States may be entitled to prevent marriages of convenience, entered into solely for the purpose of securing an immigration advantage. However, the relevant laws - which must also meet the standards of accessibility and clarity required by the Convention - may not otherwise deprive a person or a category of persons of full legal capacity of the right to marry with the partners of their choice. ${ }^{146}$

142 Section 19 of the Asylum and Immigration (Treatment of Claimants etc.) Act 2004, together with the Immigration (Procedure for Marriage) Regulations 2005 (SI 2005/15) and the Immigration Directorate's Instructions.

${ }^{143}$ Couples getting married in accordance with the rites of the Church of England were not required to comply with the Certificate of Approval scheme.

${ }^{144}$ See, for the House of Lords ruling, $R$. (on the application of Baiai and others) $v$ Secretary of State for the Home Department [2008] UKHL 53, [2008] 2 FLR 1462.

${ }^{145}$ O'Donoghue and Others v UK, No 34848/07, ECHR 2010.

146 ibid. at para.83. 
The Immigration Act 2014 has now changed the procedure for civil preliminaries for marriage, while at the same time requiring civil preliminaries rather than Church of England preliminaries in all cases where one or both parties is not a "relevant national". ${ }^{147}$ The period between the parties giving notice of the marriage and the wedding ceremony has been extended to 28 days for all marriages, to allow longer for review of the evidence submitted in order to detect potential abuse. Where one or both the parties is not a relevant national, and has limited or no immigration status in the UK, or fails to provide specified evidence of immigration status, the proposed marriage or civil partnership will be referred to the Home Office and the notice period may be extended to 70 days. ${ }^{148}$ Expertise as to the indicia of sham marriages can thus be concentrated within the Home Office.

In relation to forced marriages, a range of prevention measures are used and expertise is concentrated in the Forced Marriage Unit, a joint Foreign and Commonwealth Office and Home Office unit established in January 2005. Often the victim is taken abroad to get married, so the involvement of registration services in the United Kingdom is limited - but it is claimed that many forced marriages also take place in the United Kingdom and a factsheet has been produced for registrars. Arguably more could be done at the point when a superintendent registrar's certificate is sought. Clark and Richards compare the approach

${ }^{147}$ That is, a British citizen, other EEA national or Swiss national: see the Immigration and Asylum Act 1999 s.24(6).

${ }^{148}$ See especially ss.48-50 of the Immigration Act 2014 and s.28H and Sched.3A to the Marriage Act 1949. To avoid a reference, parties who are not EEA or Swiss nationals will have to prove that they have (a) settled status in the UK (indefinite leave to enter or remain), (b) an EU law right of permanent residence in the UK, (c) a marriage or civil partnership visa, or (d) exemption from immigration control (e.g. with the right of abode in the UK). 
adopted in England with that introduced in France. ${ }^{149}$ There the age of marriage has been raised and civil status officers must interview the parties giving notice of their intention to marry unless such an interview is impossible or is "deemed unnecessary". ${ }^{150}$ This measure was originally introduced in 2003 as a measure to prevent sham marriages, and arguably experience in dealing with sham marriages in the United Kingdom could also be drawn on in the context of forced marriages.

Both marriages of convenience and forced marriage are relevant to EU policy making since rights to family reunification are an important aspect of the right of free movement of persons in Europe. In relation to the former, the European Commission has recently produced a Handbook on addressing the issue of alleged marriages of convenience between EU citizens and non-EU nationals in the context of EU law on free movement of EU citizens (hereafter, the Handbook $)^{151}$ which aims to set out European principles, best practice and avenues for co-ordination and support of individual Member State initiatives.

How might this then impact on celebrants? The Discussion Paper produced by the Scottish Government moots the possibility that the "qualifying requirements" should include

${ }^{149}$ Brigitte Clark and Claudina Richards, "The Prevention and Prohibition of Forced Marriages - A Comparative Approach,” International and Comparative Law Quarterly 57 (2008): 501-528.

${ }^{150}$ Art.63.2 of the Civil Code. Considerable discretion can be used in deciding when an interview is necessary. An amendment to the law in 2006 now requires that if one of the couple is a minor, the interview must take place without their parents, legal representative or future spouse. Failure to comply with these rules can render a civil status officer subject to a fine.

${ }^{151} \operatorname{COM}(2014) 604$ final. 
a knowledge of the relevant legislation on sham and forced marriages, as well as some awareness training, so that celebrants are more likely to identify such marriages. And if the involvement of celebrants in preventing sham or forced marriages is seen as an important detective measure then there are good arguments for more stringent regulation of celebrants. But it must be doubted whether reliance on celebrants is likely to be effective: in the past there has been a history of complicity or complaisance on the part of clergymen and variable reporting of suspicious marriages by register offices; and individual celebrants are likely to have limited exposure to the problem. The Immigration Act 2014 channels investigation to the Home Office in order to concentrate expertise in one place, and this seems the most effective way forward.

The European Commission Handbook, drawing on expertise from across EU Member States, describes the detection of marriages of convenience as a "long haul process".

Often, it will only be possible to successfully conclude an individual case of abuse after having observed the couple and their marital conduct for an adequate period of time and collecting required evidence. ${ }^{152}$

The Commission identifies the main investigation techniques used by national authorities as: simultaneous interviews or questionnaires; document and background checks; and inspections by law enforcement, immigration or other competent authorities (in registered residences, places of employment, schools etc) and community-based checks to check whether the couple is living together and jointly administer their household. It comments that, according to experts, interviews are "the most effective

152 At p. 41. 
technique to verify whether the spouses give non-conflicting, consistent and correct information about the other spouse, their past relationship and future plans." Given this perspective, it seems unreasonable to place much weight on the role of celebrants particularly if scruples about commercialization ${ }^{153}$ mean that they are not being financially rewarded for their actions.

(b) Quality control

The 2003 consultation paper Civil Registration: Delivering Vital Change adverted to the need for a code of practice for registration authorities to ensure that an appropriate level of service was available to all, and that the importance and dignity of the ceremony was maintained. ${ }^{154}$ The debates in Parliament concerning the proposed amendments to the Marriage (Same Sex Couples) Bill also gave voice to doubts about celebrant marriages and the potential for obscure or outrageous forms of ceremony - such as Jedi marriages ${ }^{155}$ (or indeed, although it escaped parliamentary notice, Pastafarian ministers who conduct marriages for the Church of the Flying Spaghetti Monster ${ }^{156}$ ). Similar concerns are expressed in the 2014 Consultation Response. The response states that the Government wants to see "further consideration of managing risk through the use of qualifying criteria, particularly in relation to preventing sham and forced marriages, inappropriate ceremonies, and the

${ }^{153}$ See further below at 62 .

${ }^{154}$ At paras 3.1.5, 3.4.28, 3.4.34-35, and 10.4.8 ff. Cf. the Australian experience, noted above at 44 .

${ }^{155}$ See for example HC Deb 21 May 2013, col 1114-1116.

${ }^{156}$ See the Church of the Flying Spaghetti Monster website, accessed February 23, 2014, http://www.venganza.org/. 
commercialization of marriage solemnization." ${ }^{157}$ It is clear from the terminology of the response that it takes account of, and is influenced by the same considerations as the Discussion Paper. The Discussion Paper notes that two of the objectives behind the proposed introduction of the requirements are "[t]o ensure the continued reputation, dignity and solemnity of marriage and civil partnership ceremonies in Scotland" and "[t]o ensure that marriage and civil partnership ceremonies are not carried out for profit or gain."158 It notes that secondary commercial services - such as hotel, photography and tourism services inevitably attach to weddings, but expresses the view that the ceremony itself should not be commercialized. "Instead, the ceremony should focus on the couple and about them committing to each other in their faith or belief."

In fact, one of the benefits of the requirement that religious organizations solemnize marriages at a registered place of worship is that indirectly this provides quality control: it manifests a certain level of administrative organization and reliability. This is a reason for the durability of the requirement despite its appearance as a relic of former religious discrimination. The application for registration as a place for solemnization of marriages must be made by the proprietor or trustee of a building certified as a place of religious worship, and the process of registration requires that the application form be signed by a minimum of twenty householders who regard the building as their usual place of worship and then countersigned by the proprietor or trustee. There is, thus, evidence of investment in and management of property, and of a number of adherents to the religion. ${ }^{159}$

${ }^{157}$ At para.17 (emphasis added).

158 The others are the prevention of sham and forced marriages.

159 This benefit was also noted by the Law Commission Working Party in 1973: "It helps to avoid clandestine and irregular marriages by ensuring that weddings take place in buildings 
But it is not at all obvious that those contemplating marriage today desire enforced dignity and decorum over individual self-expression and the choice between gravitas and exuberance. The difficulty of defining a "belief organization" means that a system of regulation that prioritizes the parties "committing to each other in their faith or belief" is unlikely to be operable, and the Discussion Paper recognizes that identifying the elements of a celebrant service that are for profit or gain is not straightforward. Celebrants will incur legitimate expenses, as may others involved in the ceremony; there may also be training costs for celebrants, and building maintenance costs; it may be difficult to distinguish between a payment for a commercial service and a donation in gratitude for the service provided. Arguably, therefore, the maintenance of standards could simply be seen as a consumer protection measure in relation to a service provided commercially by celebrants. The important factor would then be whether the celebrant provided the type and level of service advertised. Moreover it is worth pointing out that marriage at a registered place of worship or approved premises does not escape the problem of financial incentives. Eekelaar refers to the need 'to use 'approved' premises in an environment where local authorities encourage applications for such approval as a business opportunity, and the whole system seems designed to extract the expenditure of as much money as possible," ${ }^{\prime 60}$ while many churches also regard wedding fees and charges for additional services as important sources of

which are known to, and recognized in, the community as places where marriages can lawfully take place, and which are under the control of responsible bodies who will see that the requirements of the law are observed." Law Commission, Solemnisation of Marriage, Annex, para 74.

${ }^{160}$ John Eekelaar, “Marriage: a modest proposal,” January [2013] Fam Law 83. 
revenue. ${ }^{161}$ The 2014 Consultation Response notes that the opposition of the Church of England to outdoor weddings in circumstances where religious bodies could not offer the same service, and the absence of this element in the 'wedding portfolio' of the Church would undoubtedly place it at a competitive disadvantage.

(c) Marriage model resource implications

During the debates on the Marriage (Same-Sex Couples) Bill, Baroness Berridge noted that some religious organizations were considering whether or not to continue to solemnize marriages in so far as in doing so they were performing a public registration function and might face litigation under equal treatment legislation if they refused to solemnize same sex marriages, which would have "resource implications for the government". ${ }^{162}$ If religious organizations cease to perform that role, and in the absence of any system of civil celebrants, there will be an additional need for registrars. On the other hand, if a celebrant system is introduced, the regulation of that system may itself impose certain costs. This consideration links to both to the policing of marriages and questions of quality control. For example, privatization of the solemnization of marriages in the majority of cases might allow greater conservation of resources for investigation of potential cases of fraud and duress. And the

${ }^{161}$ Weddings contribute about $£ 30$ million per annum to the income of the Church of England: a small but significant proportion of its overall income, http://www.churchofengland.org/about-us/funding.aspx (last visited March 1, 2014). ${ }^{162}$ HL Deb 19 Jun 2013, col 272. 
cost of a celebrant system will depend on the level of regulation and the amount that may be recouped in license fees. ${ }^{163}$

It is submitted that the arguments for state supervision of marriage solemnization are unconvincing. Celebrants would play a minor role in the policing of marriages, while quality control and resource management issues depend on a variety of decisions and mechanisms. Becoming a licensed celebrant could, for example, be an option for marketing purposes, rather than a legal obligation. Given the choice, a significant number of people might choose to have a trusted friend, family member or representative of a religious or belief organisation solemnize their marriage.

\section{(iii) The interests of religious organizations}

The debate over same sex marriage has once again put issues of toleration and conscience at the heart of the regulation of marriage. Religious organizations are divided on the question of same-sex marriage. Some welcome it, seeing it as an opportunity to extend care to LGBT members of their community, and to bring the gospel to a new audience. Others strongly oppose it - arguing that marriage is and should remain the union of a man and a woman. To meet this position, the Marriage (Same-Sex Couples) Act 2013 contains the "quadruple lock" described above ${ }^{164}$ to protect the position of those who do not want to solemnize such marriages. But doubts about the efficacy of the quadruple lock remain, and

${ }^{163}$ As noted above at 44-45, Australia has recently introduced cost recovery measures through the fees imposed at the stages of application for a license and renewal or registration. ${ }^{164}$ At $27 \mathrm{f}$. 
many of those who currently officiate at religious marriages would withdraw from that activity if they felt compelled to solemnize same sex marriages. ${ }^{165}$

Indeed, the issue of recognition of same sex unions as marriage has provoked a much wider debate within church communities internationally as to whether "civil marriage" is now - looking at the accumulated changes to the institution - so distinct from "Christian marriage" that the churches should withdraw from their role in the ceremony. The founder of the Radical Orthodoxy movement, Professor John Millbank, has suggested that:

Perhaps, in order to safeguard the churches from pressures to conform to the norm, we should now welcome a withdrawal from the churches of their rights as a civil marriage broker. This would leave the churches free, in their turn, to claim that only natural and sacramental marriage are genuinely "marriage," while state marriage is mere civil union. ${ }^{166}$

${ }^{165}$ See for example the comments of Baroness Berridge at HL Deb 8 July 2013 col 101. 166 "The impossibility of gay marriage and the threat of biopolitical control," ABC Religion and Ethics, April 23, 2013, accessed February 23, 2014, http://www.abc.net.au/religion/articles/2013/04/23/3743531.htm. Financial incentives as well as tradition weigh against a rapid acceptance of this idea (see above at fn 162). There might also still be some question under equality legislation of when services were provided to the public, and when they were private. 
More concrete steps in this direction have been taken by those who have signed up to the "Marriage Pledge" promoted by Ephraim Radner and Christopher Seitz and set out in the publication First Things. ${ }^{167}$ The signatories agree that

The new definition of marriage no longer coincides with the Christian understanding of marriage between a man and woman. ... To continue with church practices that intertwine government marriage with Christian marriage will implicate the Church in a false definition of marriage.

They commit themselves to "disengaging civil and Christian marriage in the performance of our pastoral duties", refusing to "serve as agents of the state in marriage". The Marriage Pledge has so far attracted a rather small number of signatories, although it has been discussed in both the United States and the United Kingdom. Unsurprisingly, the viewpoints expressed reflect both the particular theological stance of the writer on the nature of marriage and the legal context within which the writer is situated. Thus the reaction of a conservative Reformed Christian in the United States, supporting covenant marriage, embedded in a tradition of separation of Church and State, and generally hostile to state encroachment on the private sphere will be radically different to that of a Church of England clergyman, a member of the established church, whose role goes beyond solemnization of the marriage and includes civil status registration functions. ${ }^{168}$

167 “The Marriage Pledge,” First Things, accessed December 31, 2014, http://www.firstthings.com/marriage-pledge.

${ }^{168}$ In the United States there is also a significant literature on the privatisation of marriage which is completely absent in the United Kingdom. 
The stance of the Church of England on this issue is apparent from its response to the consultation on marriage equality:

"In law, there is one social institution called marriage, which can be entered into through either a religious or a civil ceremony. To suggest that this involves two kinds of marriage is to make the category error of mistaking the ceremony for the institution itself." 169

Furthermore, specifically in relation to the marriage pledge, it has been noted that Anglican clergy are unlikely to become signatories since

"[a]n overarching requirement in England and Wales is the common law duty on the Church of England and the Church in Wales to perform marriages. ... This arises

${ }^{169}$ A Response to the Government Equalities Office Consultation - "Equal Civil Marriage"from the Church of England (June 2012) 4 (hereafter Equal Civil Marriage). See also for a Catholic perspective, Edward Peters, "Distinguish civil marriage from sacramental? Of course. Divide them? No!"' (In the Light of the Law, November 25, 2014), accessed December 31, 2014, https://canonlawblog.wordpress.com/2014/11/25/distinguish-civilmarriage-from-sacramental-of-course-divide-them-no/ and idem, "I guess one in three Americans don't know a good thing when they see it" (In the Light of the Law, December 4, 2014, accessed December 331, 2014, https://canonlawblog.wordpress.com/2014/12/04/iguess-one-in-three-americans-dont-know-a-good-thing-when-they-see-it/. But cf. John Milbank's distinction between marriage and civil union (above at fn.166) 
from the Church of England's status as the established church in England, and the 'vestiges of establishment' pertaining to the Church in Wales."

The duty to perform marriages is a duty owed to all parishioners, whether or not they are members of the Church. ${ }^{170}$ Any change in this duty would require a change in the law, and the refusal of a clergyman to solemnize marriages goes beyond an issue of individual conscience. Withdrawal from this function would therefore be a seismic change and not one likely to occur while the quadruple lock holds fast.

But the debate continues internationally and further internal and external challenges to the position of churches and other religious organizations who are unwilling to participate in the solemnization of same sex marriages can be expected. The issue is not just one of continued reference to "place of worship" in the requirements for a valid marriage, but also one of the place of religion in the public sphere. Opposing the call to disengage from the solemnization of marriages that produce civil effects are those who consider that by doing so the churches would fail in their "duty to proclaim the truth about marriage in the secular order and matrimony in the religious", ${ }^{171}$ and believe that

\footnotetext{
${ }^{170}$ Subject to certain statutory conscience clauses and the rules on same sex marriage introduced by the 2013 Act. See David Pocklington, “The Marriage Pledge - It's Relevance in Europe" (Law and Religion UK, November 24, 2014), available at http://www.lawandreligionuk.com/2014/11/24/the-marriage-pledge-its-relevance-ineurope/ and Equal Civil Marriage, 7.

${ }^{171}$ Edward Peters in "The Church and Civil Marriage," First Things, April 2014, accessed December 31, 2014, http://www.firstthings.com/article/2014/04/the-church-and-civilmarriage.
} 
the public platform provided by state recognition of religious marriage ceremonies should not willingly be abandoned.

There is a diversity of views as to the role that religious bodies should perform in marriages that produce civil effects, but a shared interest in ensuring continued freedom of religion and the opportunity to advocate on matters of conscience in the public sphere.

\section{(iv) A radical solution?}

If the state's interest in the solemnization of marriages is strictly limited, as suggested above, then perhaps a thorough reappraisal of the formal requirements for marriage is in order. Eekelaar has proposed a "radical solution" in which state interests are focused on the marriage preliminaries and the attestation of the consent of the parties to the marriage, leaving the ceremony itself unregulated.

Most people see marriage as a major event in their personal lives, which for many can only be adequately expressed if it has been brought about in a manner in accordance with a deeply held belief, or in a way that holds strong meaning for them. The logical (if radical) outcome of recognizing this is that it should not matter what type of ceremony accompanies the formation of the marriage if it fulfils those requirements for the parties... [T]his strategy would make the secular law relating to the consequences of marriage available to all unions which the parties see as being a marriage, provided only that certain preliminary formalities are fulfilled. Nothing needs to be stipulated about the ceremony itself, where it is to be held, or even the form of words used. Agreement between the parties has always been the essence of marriage, and all that needs to be attested is that the parties have, at a certain time and place, agreed freely to enter into marriage with one another. 
A major advantage of the mandatory civil ceremony required in France and many other civil law jurisdictions is legal certainty: the requirements for a valid marriage are clear and so it is easy to disseminate information about them. It is easier to insist on strict enforcement if the parties can be expected to know and understand the legal requirements. But the uninspiring character of purely formal civil ceremony and the need for two ceremonies for those who want a religious or belief marriage mean that it has never acquired popularity as an option for England and Wales. On the other hand, if the formalities of the ceremony are effectively reduced to the witnessed exchange of consents, this in itself is an easy message to communicate - along with a strong emphasis on the necessity of first obtaining a license. ${ }^{172}$ Any necessary investigation of the parties' capacity or desire to marry is then focused at the licensing stage - where relevant with appropriate Home Office assistance. Since this seems to be the direction that the law is already taking, the radical solution would not require a significant policy change. As is currently the case in Scotland, the license or schedule would be a form requiring details of the parties, the witnesses and any celebrant, which would then be signed by the parties and witnesses at the time of the wedding and returned to the register office. $^{173}$

Such an approach would certainly accommodate the interests of the intending spouses. It would also accommodate the interests of non-religious belief organization, and individual

172 There is no space here to discuss how far such an approach, with its clearer message, might also help to resolve problems arising from the large numbers of unregistered Muslim marriages in the United Kingdom.

173 This is also similar to the approach adopted in jurisdictions where a temporary celebrant can be authorised, since no particular qualifications or training are required in this situation. 
celebrants who currently offer a service which is not recognized as having any civil effects. As to whether it would accommodate the interests of religious organizations, there are positive and negative considerations. It would provide a more flexible framework within which to place religious marriage ceremonies, since the minister or other celebrant would not be performing a function essential to the 'civil' marriage itself, and it might allow religious organizations to 'compete' more effectively in the market for celebrancy services, since location would be less of an issue. This would provide the continued opportunity for such organizations to proclaim their views on marriage and to treat a marriage service as an act of worship. On the other hand, there is also the risk that religious ceremonies would instead lose some of their attractiveness if a wider range of alternatives became available. Furthermore, a more flexible framework would in all probability be detrimental to institutional discipline on issues such as same sex marriage. These considerations will be evaluated differently by different religious organizations.

A practical problem associated with the radical solution is the difficulty in ensuring that a marriage will be registered once it has been celebrated. ${ }^{174}$ The objectives of the registration system are twofold: to create legal documents that are used to establish and protect the civil rights of individuals, and to establish a data source for the compilation of vital statistics. Many countries use the criminal law to enforce registration, but this is clearly less effective than control at the point of delivery. Nevertheless, a change in the system of registration was proposed in the context of the modernization program Civil Registration: Vital Change, adopting an approach similar to that employed in Scotland. Under that system a schedule is issued by the registration authority on completion of the preliminaries, and is returned after the ceremony with the signatures of the celebrant, the couple getting married and the

${ }^{174}$ One could argue for a state interest in combining solemnization and registration functions. 
witnesses. ${ }^{175}$ Moreover, in an era when cohabitation rather than marriage is increasingly common, a significant proportion of marriages take place abroad, ${ }^{176}$ and many marriages end in divorce, methods for capturing the demographic details of the nation other than the registration of marriages must of necessity be utilized.

Practical issues are not the predominant consideration in regulating marriage, and the law has proved resistant to change. Traditions are strong. Throughout the centuries, each amendment has proved controversial. Rather, the law has developed through a series of minor accretions. On the other hand, even a measure as controversial as the Marriage (Same Sex Couples) Act 2013 can be steered through Parliament if the government of the day is sufficiently determined. But it must be noted that the 2013 Act was limited in purpose, and that all efforts to extend the range of reforms to the law of marriage during its passage through Parliament were rebuffed.

\section{(v) Conclusions}

If not in the short term, then at least in the medium term, significant change in the English law on the solemnization of marriages seems likely - driven by some combination of individualism, equal treatment concerns and the repercussions of same sex marriage. It is

175 Traditionally the best man takes responsibility for returning the schedule, although legally it is the responsibility of the couple: see Civil Registration: Delivering Vital Change, para.

\section{$3.4 .106 \mathrm{ff}$}

${ }^{176}$ No statistics relating to such marriages are available, but a range of newspaper reports and polls suggest a steep climb in the numbers during the last ten years. They are thought to account for approximately $20-25$ percent of all marriages. 
implausible that marriage at a "registered place of worship" will survive this change, but this is a reform that is long overdue. The particular political and religious factors and social concerns that led to this form of regulation no longer exist and a comparative survey shows that English law is complex and anomalous.

While a system of licensed celebrants is one plausible way forward, the more radical solution described above deserves consideration. Indeed, perhaps it is not so radical. In a certain sense it even looks like a return full circle to the ecclesiastical law rule that a valid marriage required only an exchange of promises. A return to marriage "in a house, in the street, in the fields, or at a tavern". But, in fact much would have changed. Apart from a requirement of witnesses, the preliminaries to marriage and machinery for registration have become increasingly robust, with the potential to obtain any requisite evidence of status and capacity to marry, ${ }^{177}$ obviating the publicity function of the ecclesiastical law rules and their statutory descendants.

As the rules on licensing become increasingly complex, perhaps it is time for radical simplification of the requirements for the marriage itself: a radical simplification which removes the need for the state to involve itself in the distinction between religious and nonreligious ceremonies, does away with the distinctions based on the discriminatory provisions of previous centuries, and provides a bright line rule establishing license and witnessed consent as the criteria for a valid marriage.

${ }^{177}$ Further measures to strengthen the preliminaries are currently under consideration by Parliament: Immigration, HC Bill (2013-14) [128]. 